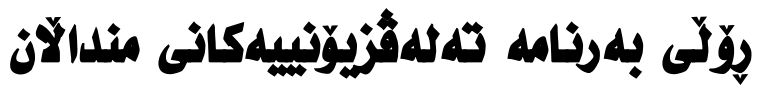

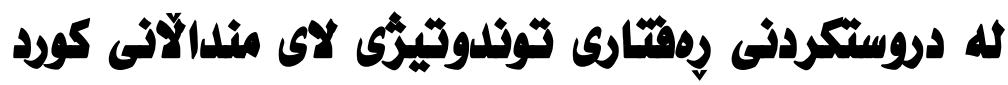

\section{جوان بهاء الليز على}

بهاشى رِاكهياندن، كوليَّْى زانسته مروّثايهتيهكان، زانكوَى سليّمانى، سليمانى، هـريّمى كوردستان، عيّراق. زيمـايل: kwwan.bahaden@koyauniversity.org

\section{سلام نصراللين محمد}

بهاشى راكهياندن، كوليَّْى زانسته مروّثايهتيهكان، زانكوَى سليّمانى، سليّمانى ،هـريّمى كوردستان، عيّراق. salam.mohammed@univsul.edu.iq :ئيمهيل

ئامانجى ئهم تويّزينهوهيه بريتيه له ئاشكراكردن و خستنهرووى ئهو بهرنامه و بابهتانهى كه مندالهكان بهكثتيى

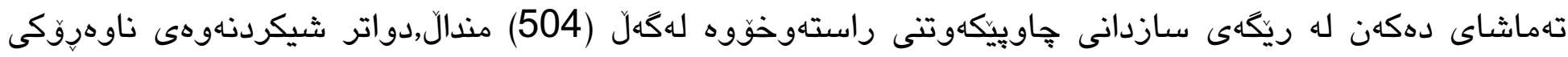

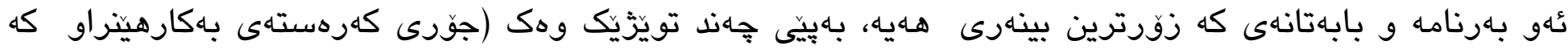

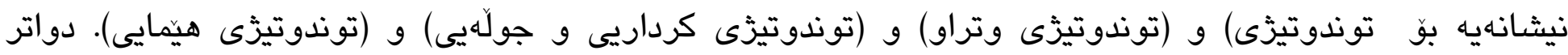

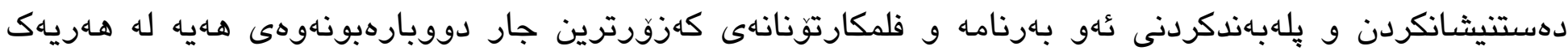

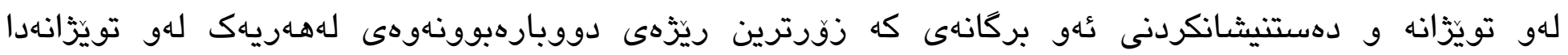

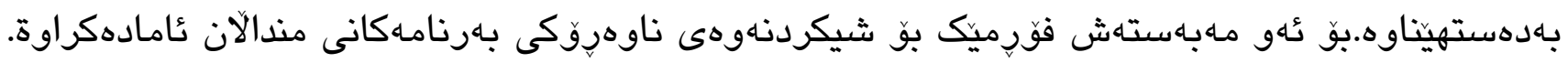

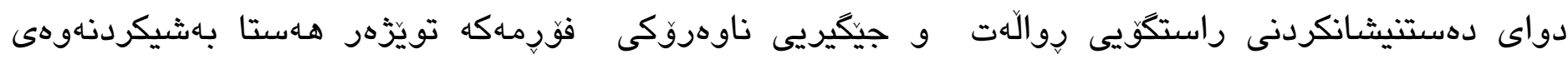

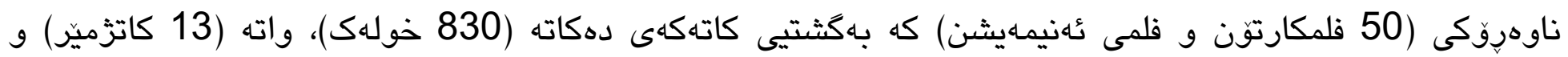

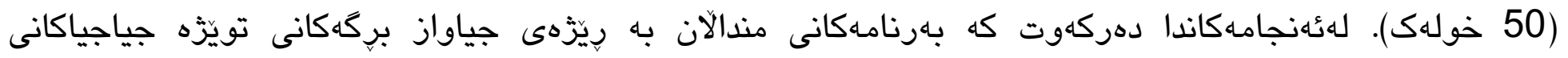

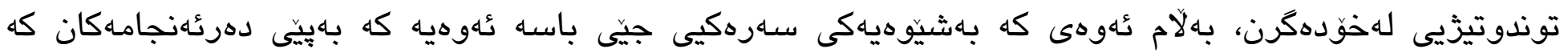

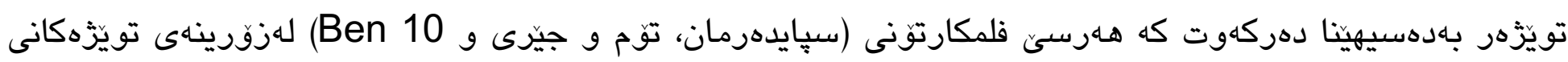

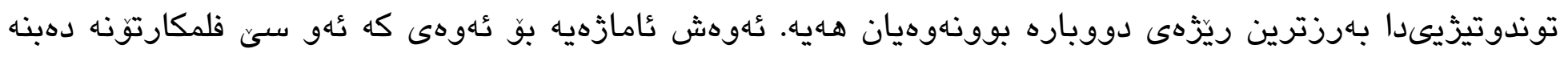

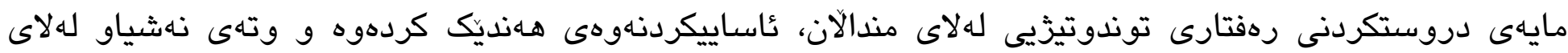




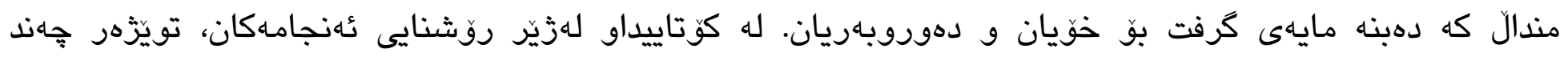
راسبارده و بيّشنيازيكى بِيشكهشكردووة.

كليله وشهان : روّل ، بهرنامه تهلهثزيونييهكانى مندالان ، رهفتارى توندوتيزّى.

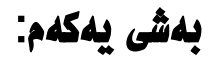 \\ ناسائلن به تويَّرينهوودكه}

\section{يلمكهم: كيّشهى تويّزئنهومكه}

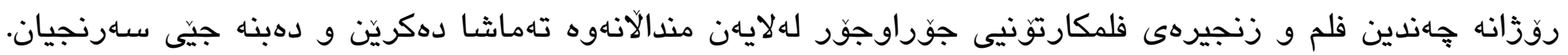

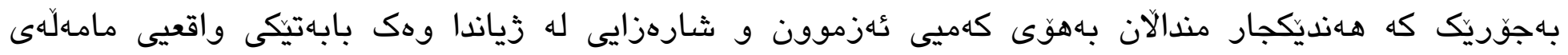

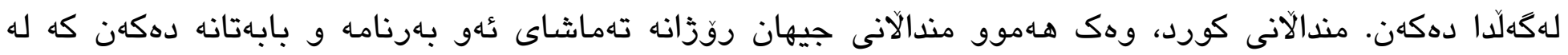

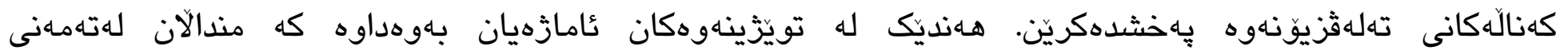

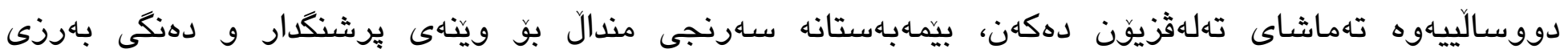

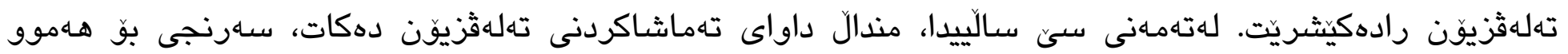

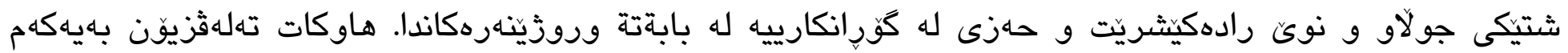

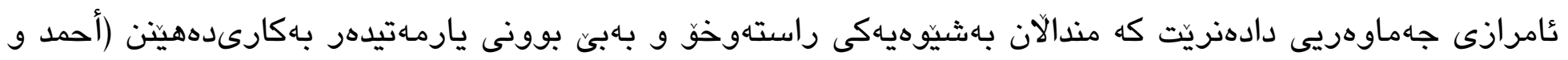

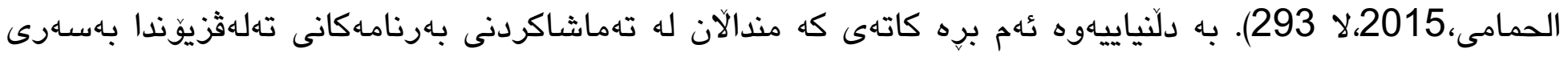

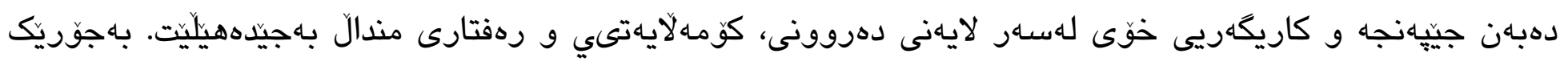

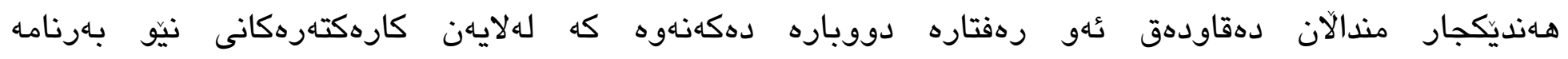
تهله ثزيونييه كانهوه ئهنجامدهدريت.

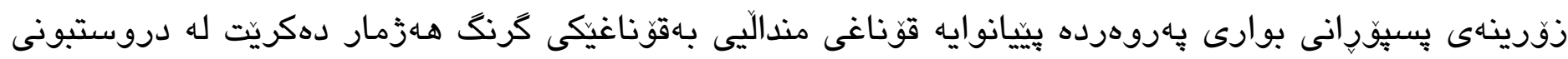

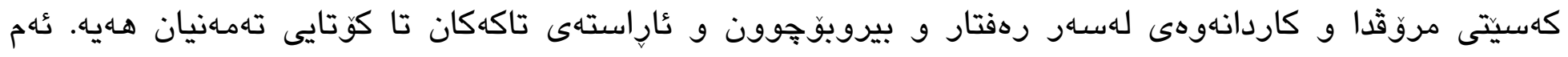

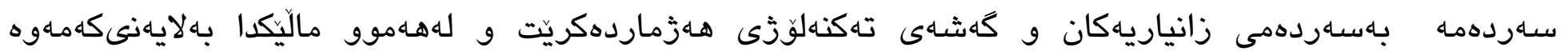

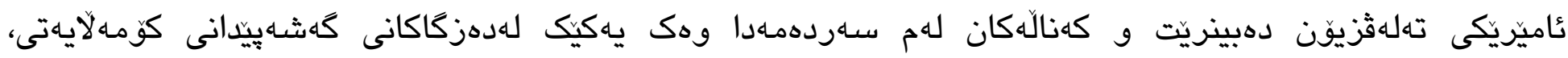

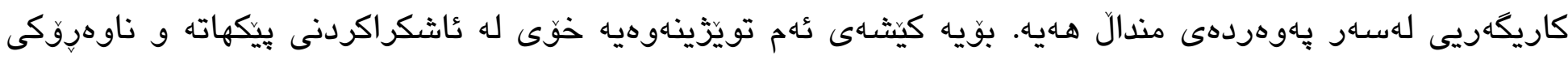

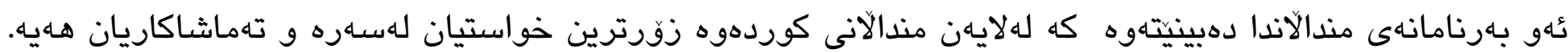

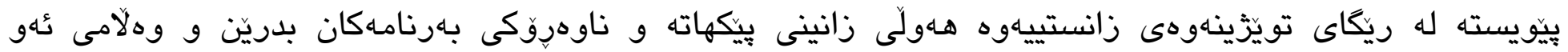


برسياره بدريتهوه كه (ئايا ناوهرِكى ئهو بهرنامانهى مندالآن كه لهلايهن مندالآنهوه زوّرترين خواستيان لهاهـره،

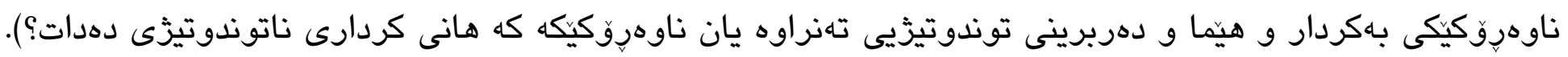

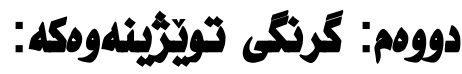

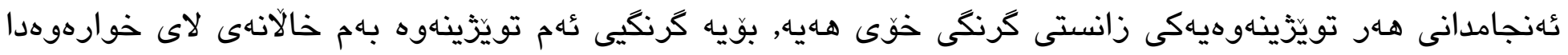

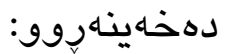

1. ئهم تويزّينهوهيه ئهو بهاهنامانه ئاشكرادهات كه لهلاى مندالانى كورد جيَّاى بايهخن و كاتيكى زور له تهماشاكردنيان بهاهر دهبهن.

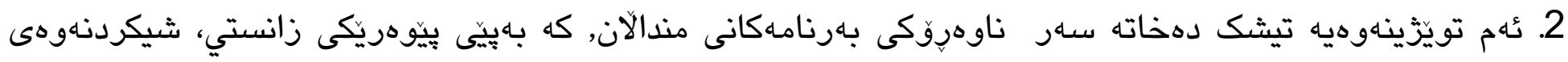

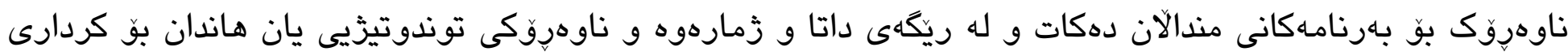

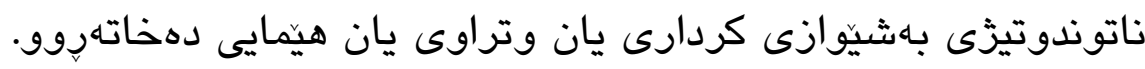

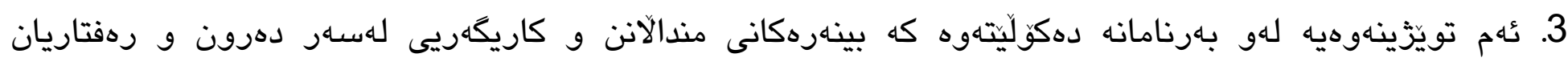

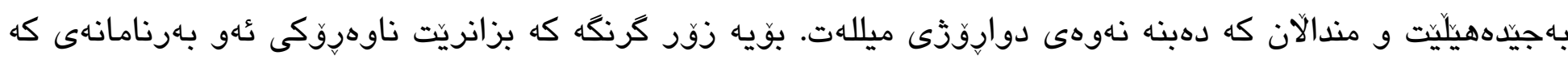

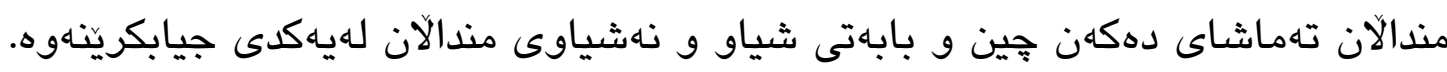

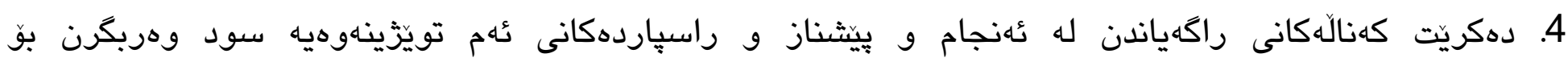

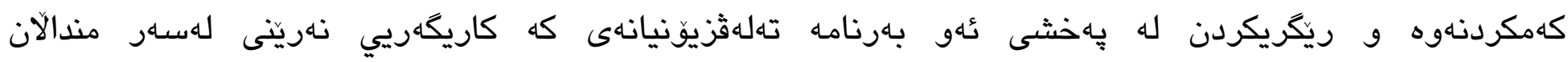

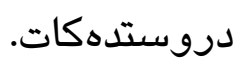

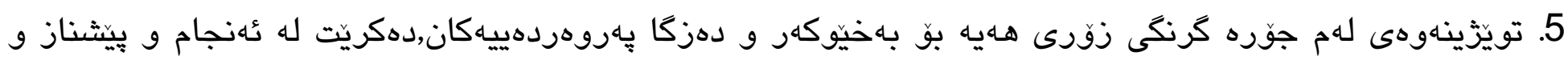

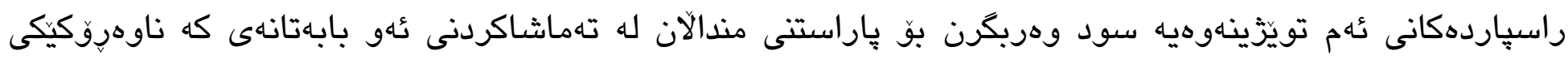

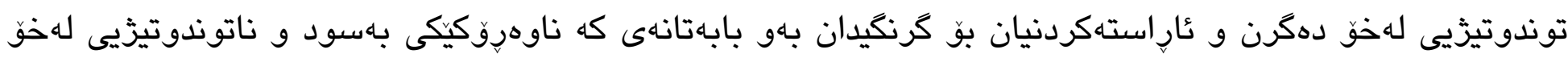
دمكرن.

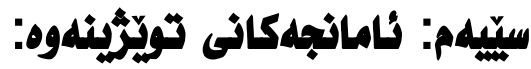

ئامانجى ئهم تويّزينهوهيه لهم خالآنهى خوارةوةدا خوّى دهبينيتهوه:-

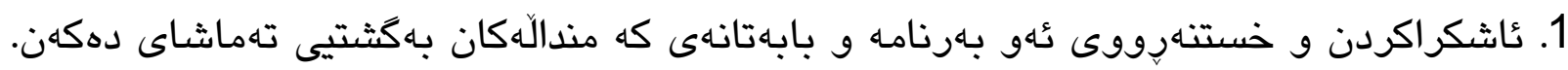

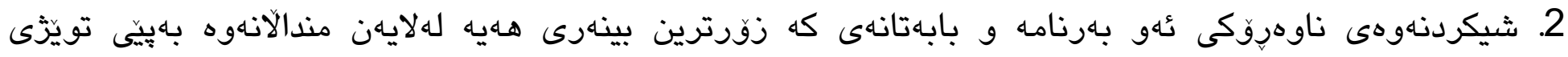

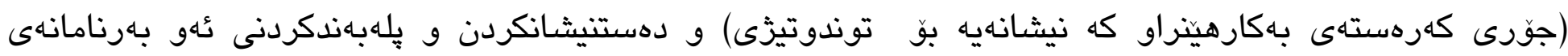

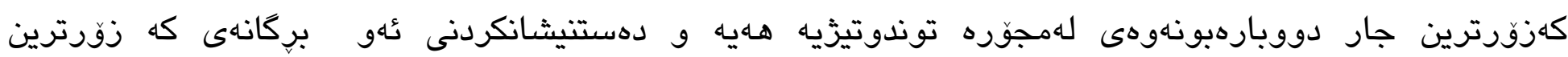

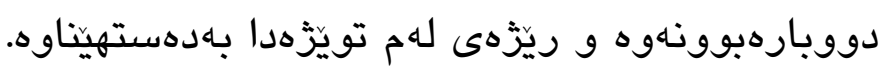




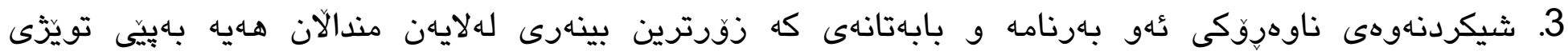
(توندوتيزى وتراو) و دهستنيشانكردنى ئهو بهرنامانهى كه زوقرترين جار دووبارهبونهوهى لهمجورده توندوتيزيه هـيه

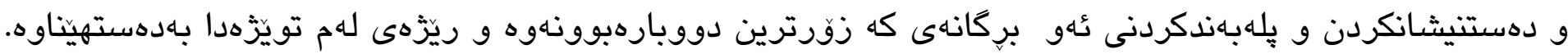

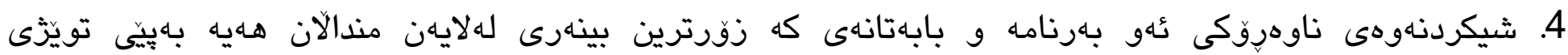

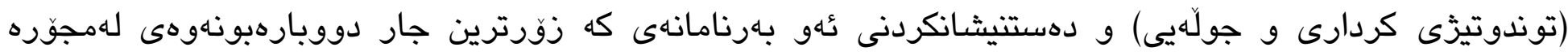

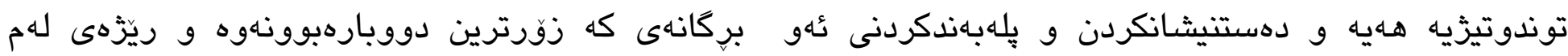
تويَّهدا بادهستهيناوه.

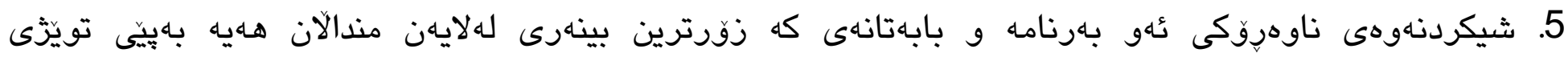

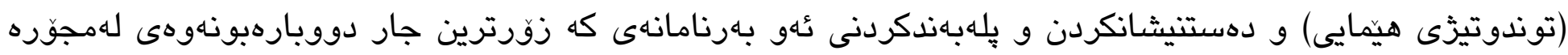

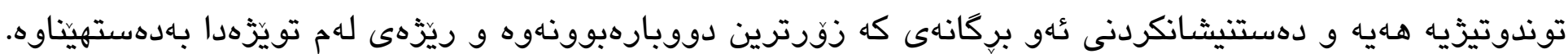

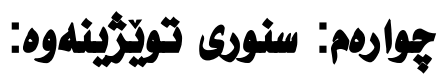

سنورى ئهم تويَزَينهوهيه ئهو بابهت و بهرنامه تهلهزيونيانه دهكريتهوه كه لهلايهن ئهو مندالآنهوه تهماشا دهكريّن

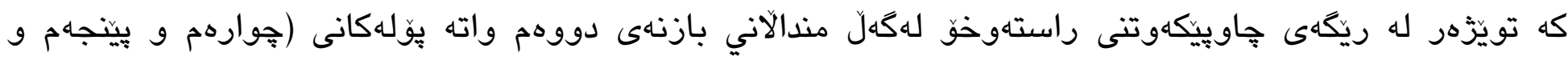

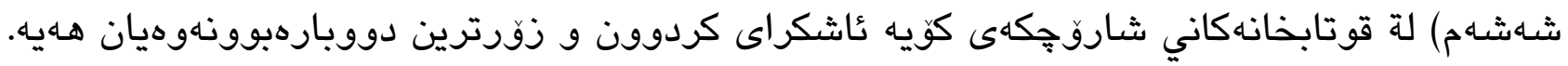

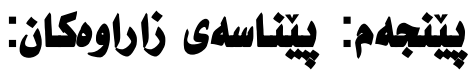

• بهارنامه تهلهزَيوّنيهكانى مندالان

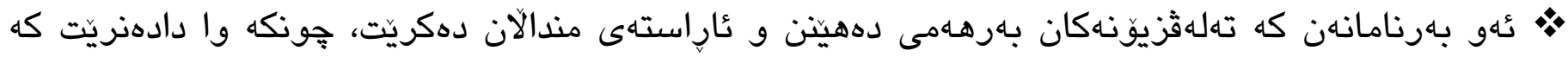

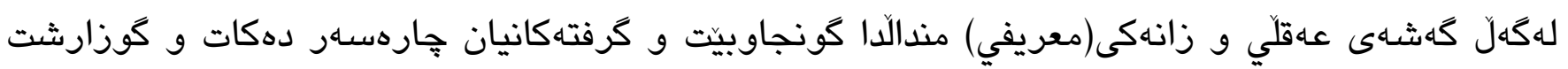

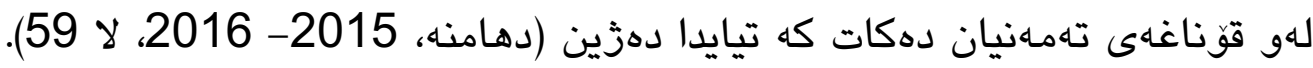

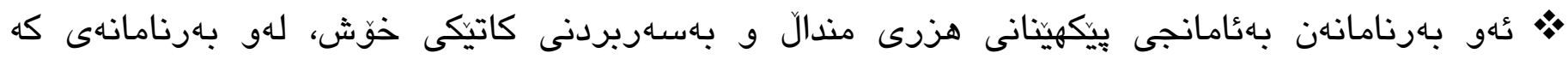

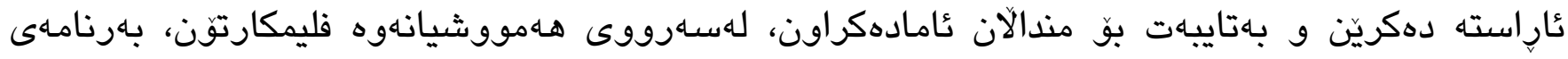

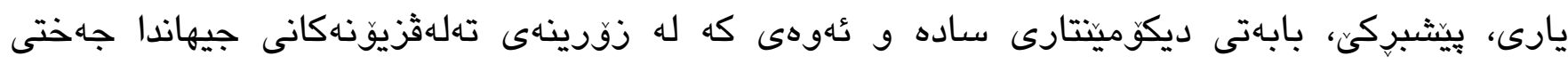

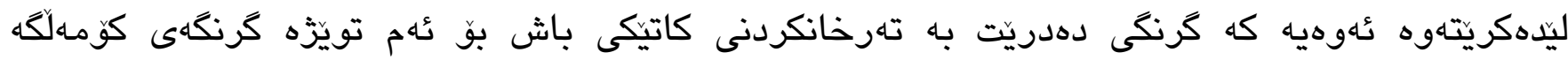

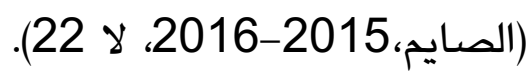




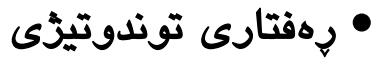

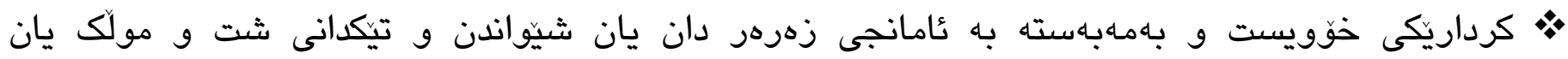

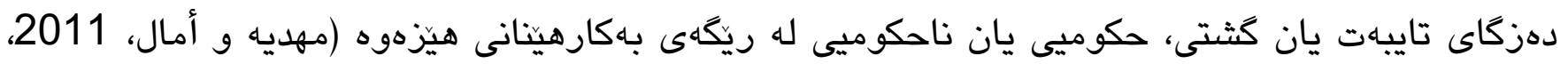

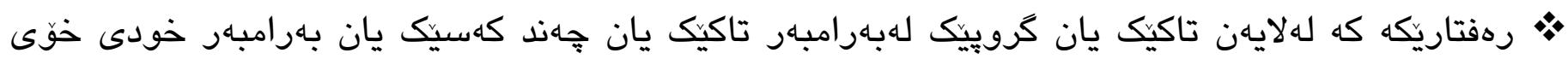

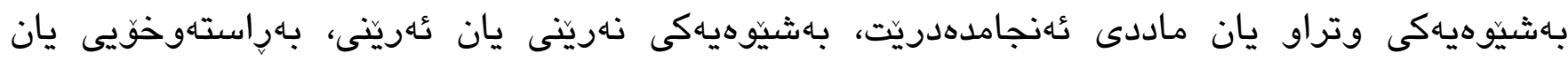

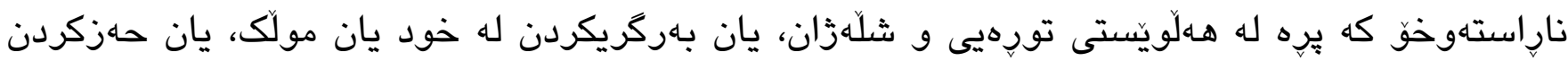

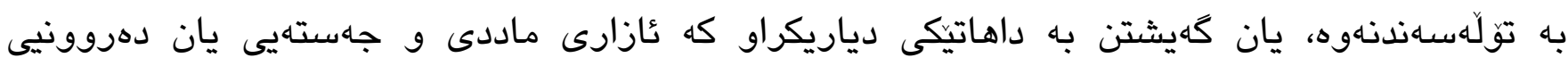

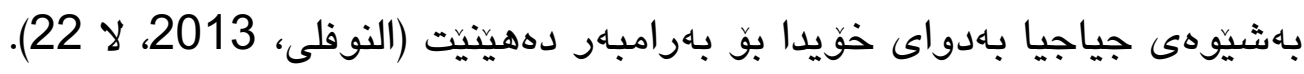

\section{بلاشى دووهم:

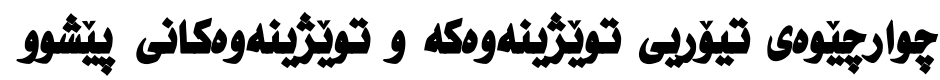

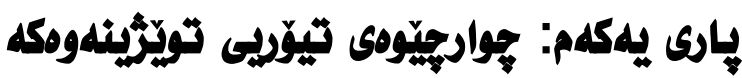

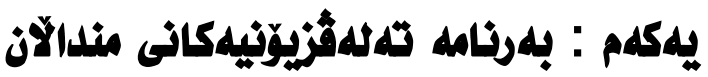

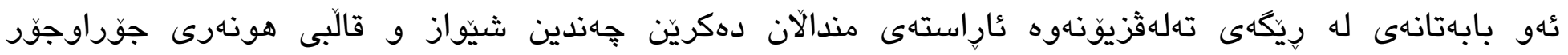

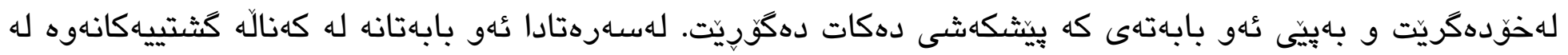

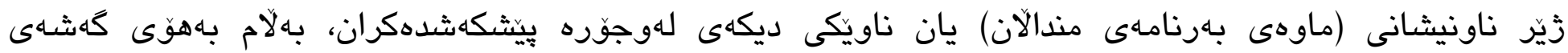

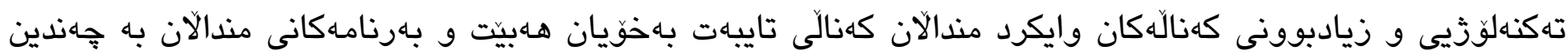

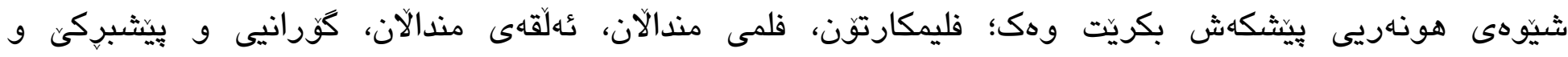

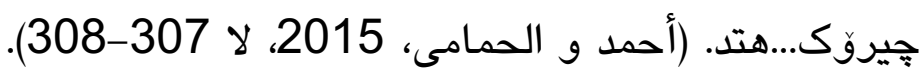

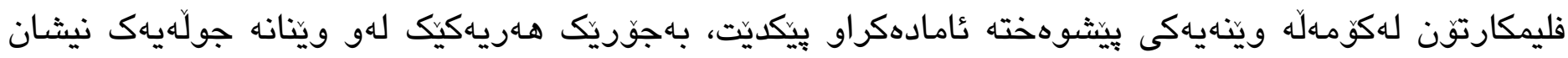

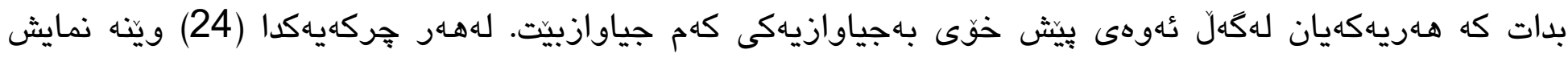




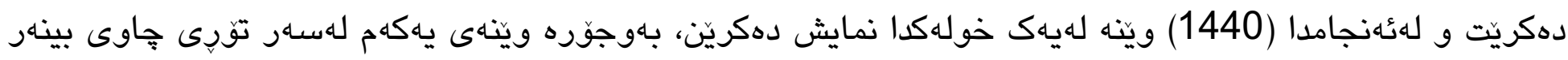

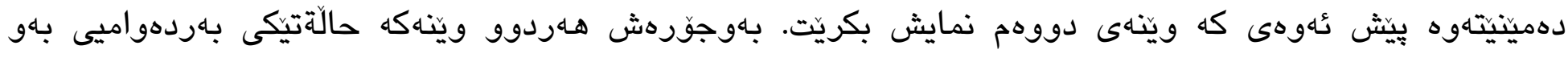

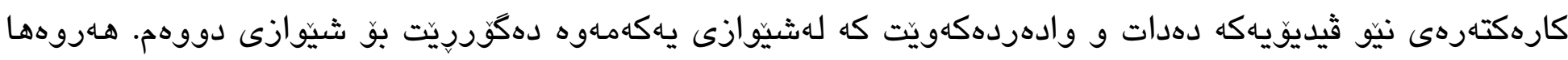

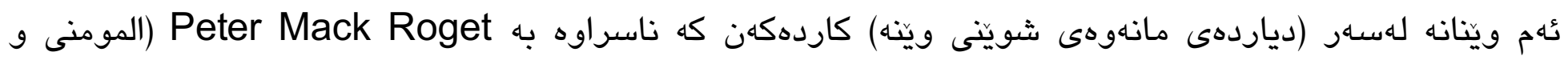

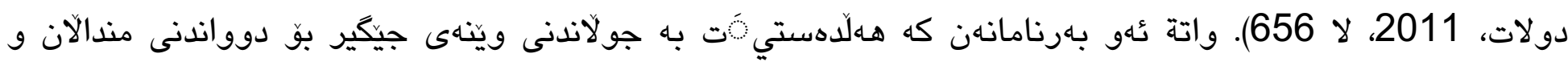

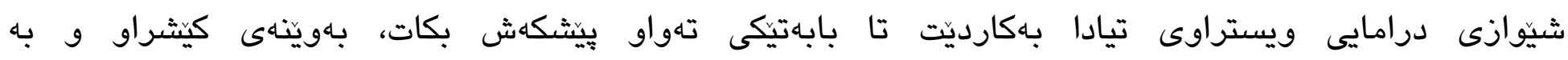

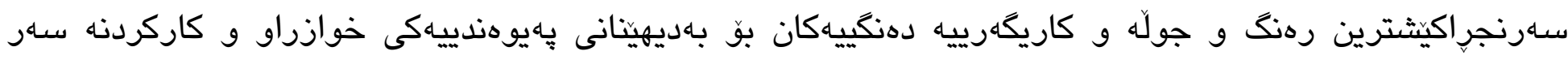

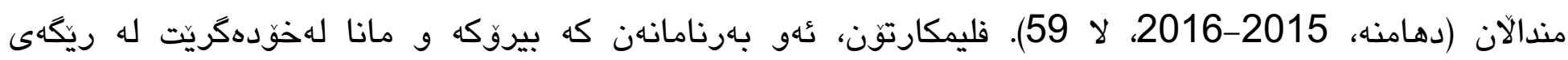

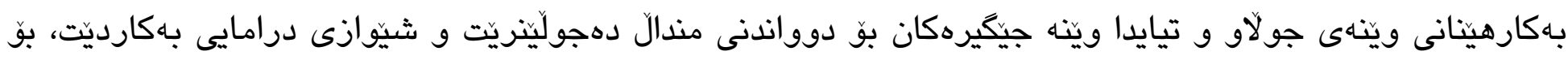

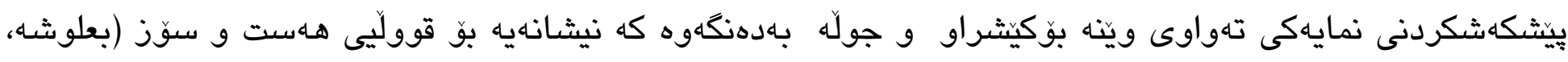

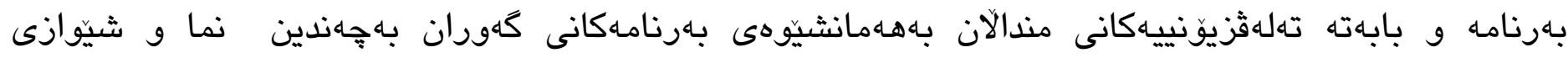

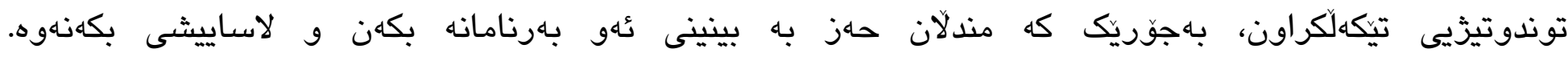

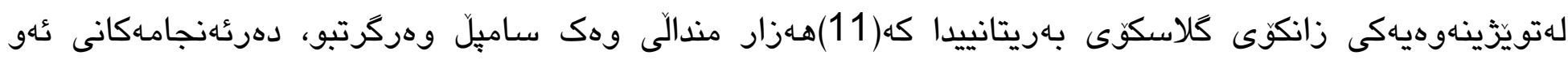

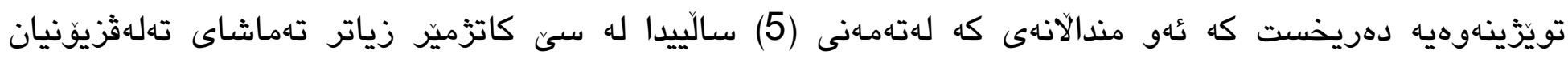

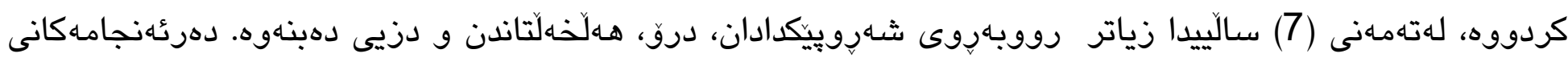

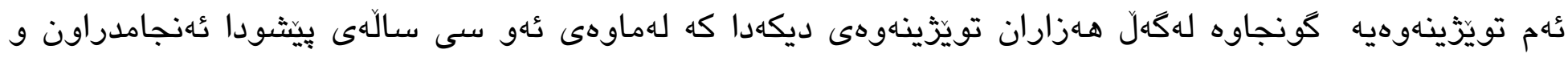

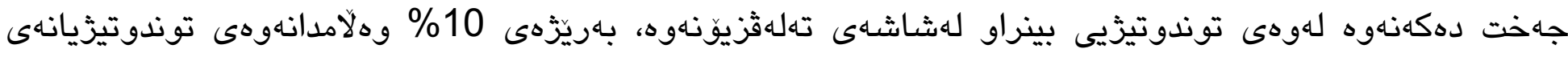

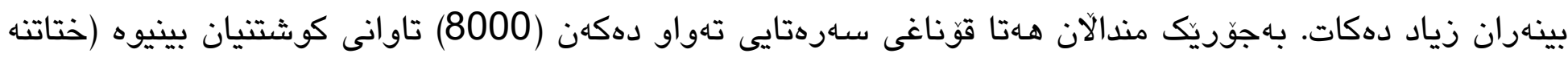

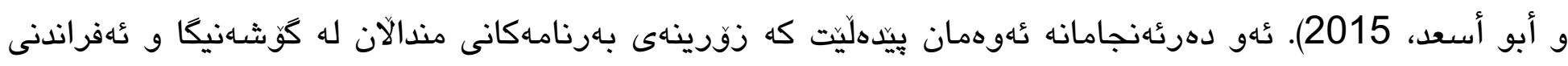

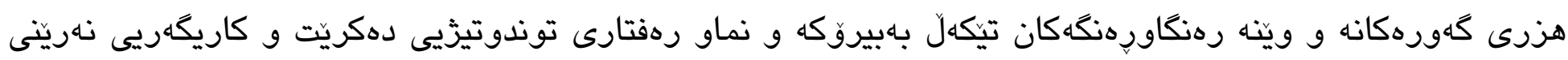
لهاسر مندالان باهيّدهيلّيت. 


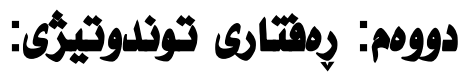

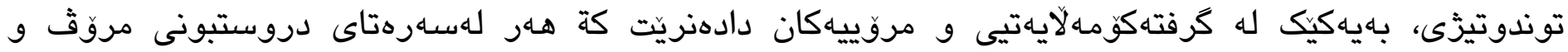

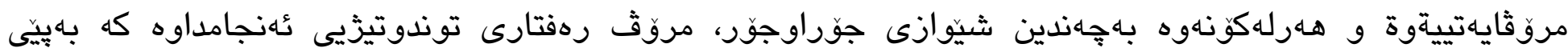

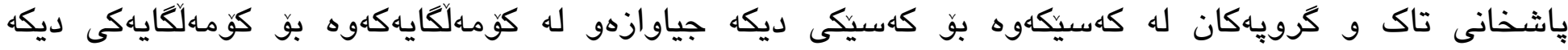
دهكَّرِيت.

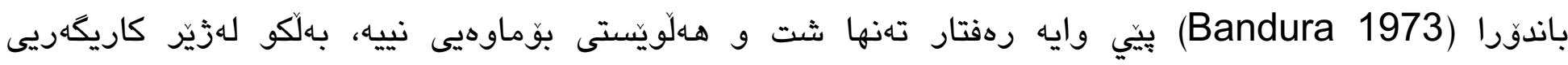

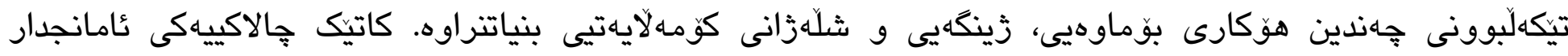

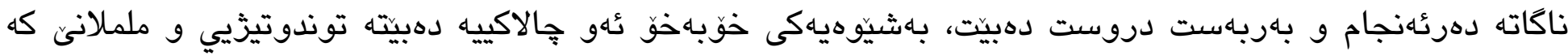

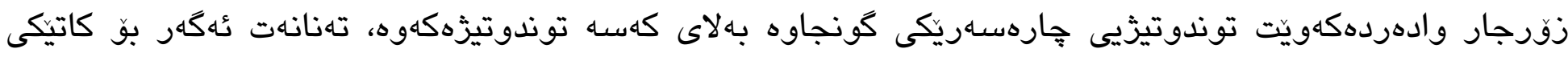
كورتيش بيّت، بهتايبهت كاتيك كه جارهسهرى ديكه لهبهردهستدا نامينيتت (الزغبى، 2017، لا 15). توندوتيزى، رهفتاريكى كردارييه يان وتراوه كه هيَز و هـهرهشهردن لهخودهكريتيت و دهبيتههوَى عازاركهياندن به خودى خوّى يان

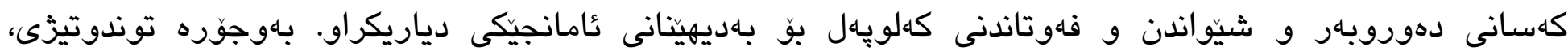

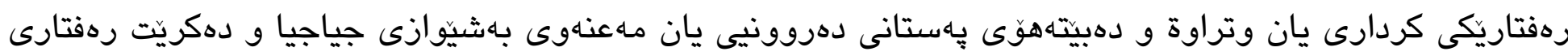

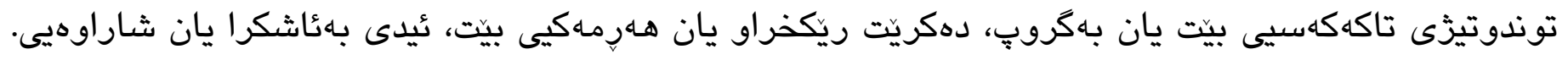

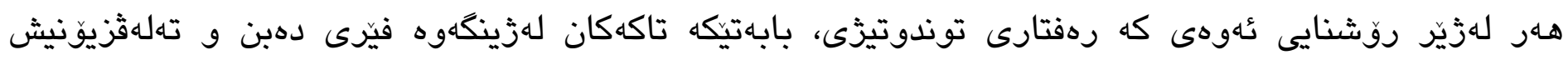

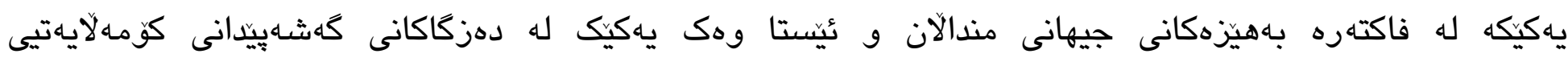

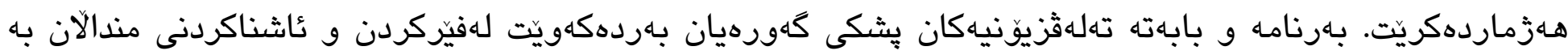
رهنتار و بيركردنهوهى توندوتيزيانه. تويّزينهوهكان سـالماندوويانه كه بينهرى تهلهثزيوّنهان فيّرى رهفتارى توندوتيزيى و نمونهى كوشتن دهبن و ميدياكان روّلِيان له وروزاندن و دروستكردنى كيثشه له نيّو جهماوهردا هـية (دحلان، 2003، لان 801-81).

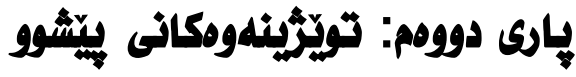

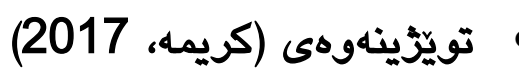

تويّزينهوهكه بهناونيشانى (العنف فى برامج الأطفال الكرنونية فى قناة سبيس تون ـ در اسة وصفية تحليلية للمسلسل الكرنونى

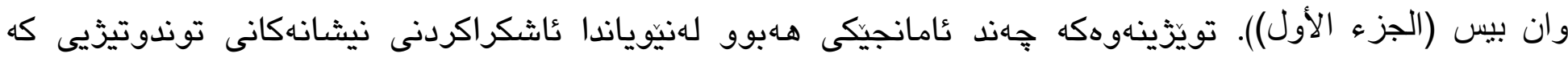

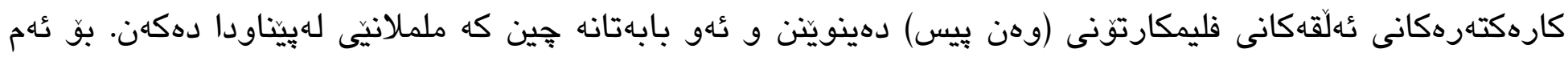
مـهبهتهش تويّزهر ريّبازى وهسفى ناخشيكارى بو (8) نُّلّه بهكارهيناوه. دواى كوكردنهوهى داتاكان تويَزينهوهكه 


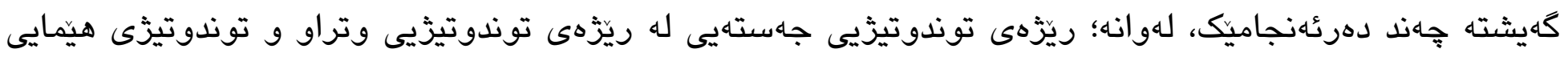

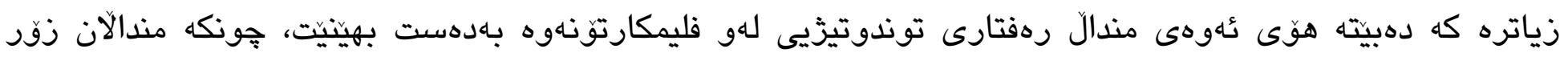

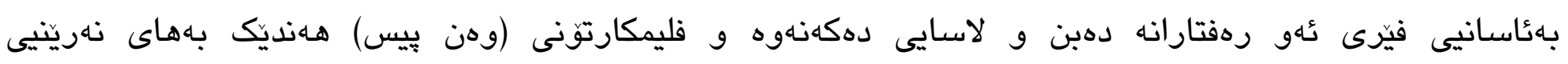

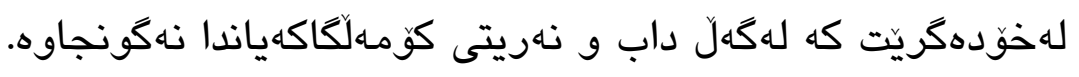

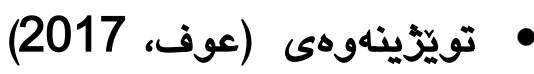

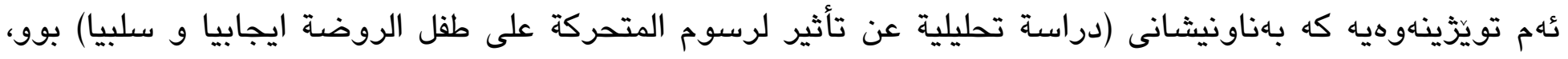

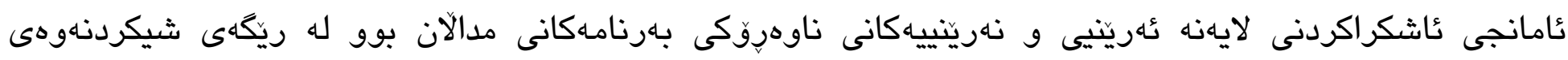

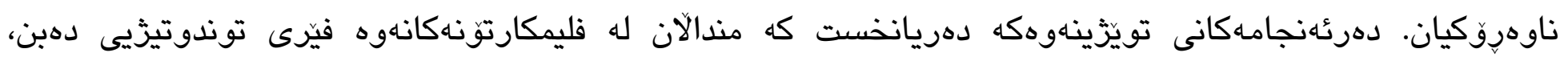

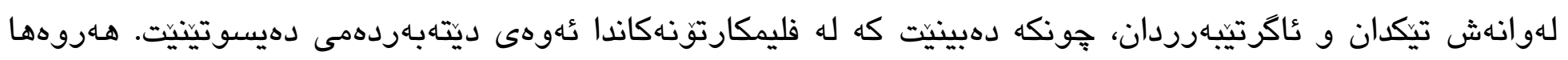

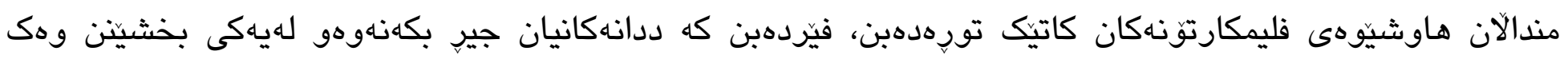

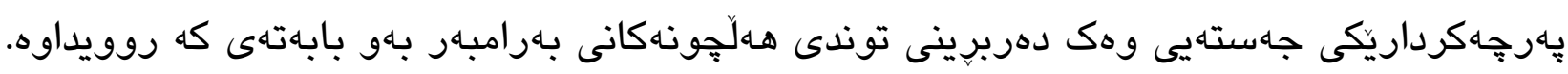
تويَّينهاوهى (القواسمه و الخزاعله، 2017)

تويخزينهوهكه بهناونيشانى (مظاهر العنف التى تتضمنها برامج الأطفال فى قناة Spece Toon الفظائية لدى طلبة

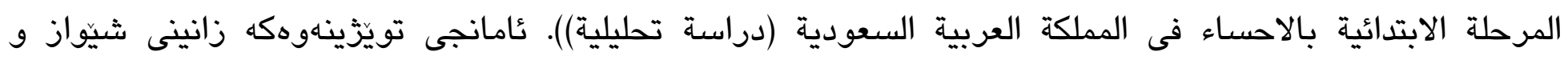

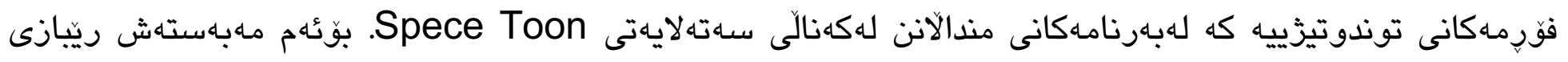

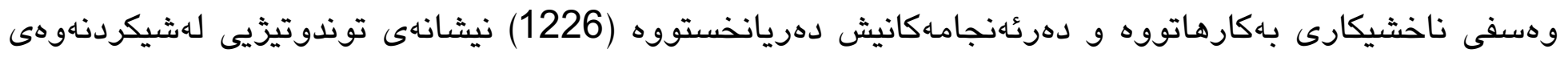

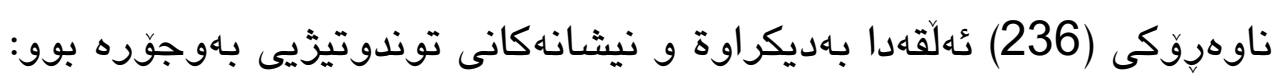

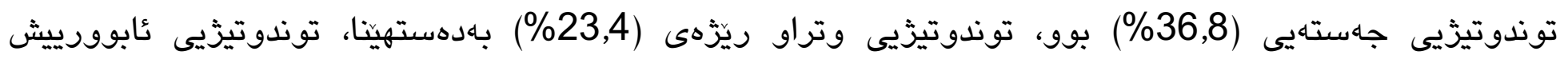

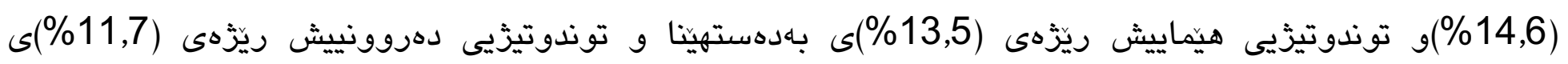




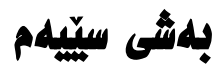

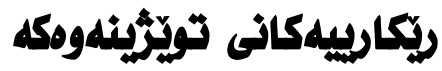

له بهاشهدا تويَّزهر ئهو هـنكاوه ريّكاريانه دهخاتهروو كه لهم تويَّينهوهدا ئهنجامدراوه:

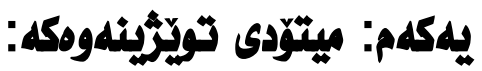

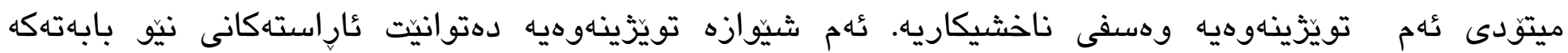
دهستنيشان بكات و تايبهتمهندييهكانى بهشيّوهيهكى زانستيى ريكخراو دهربخات, نهك بةتهنها يشت بهبوّهونه

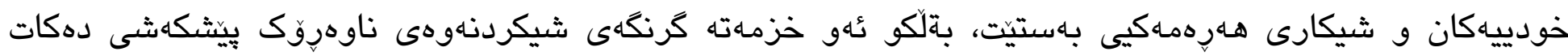

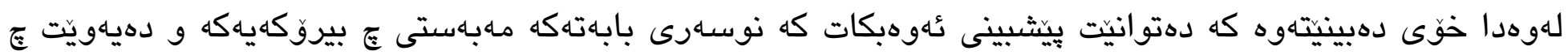

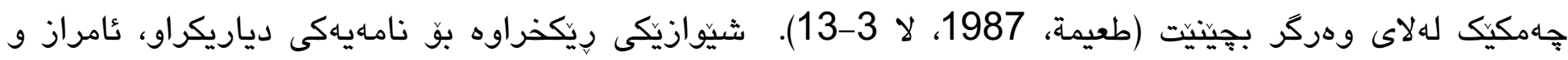

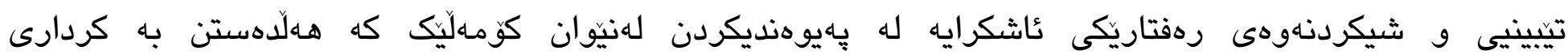

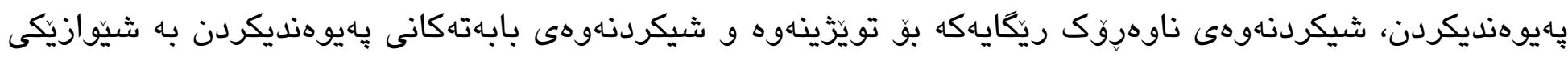

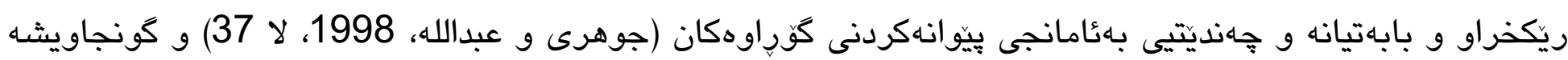

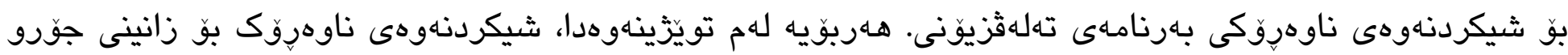

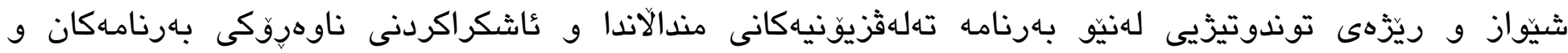

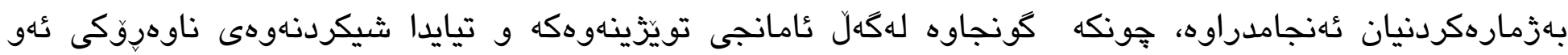

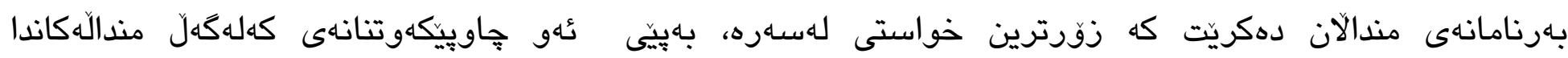
تُهنجامدراون.

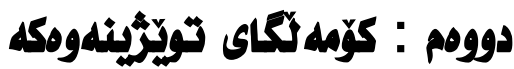

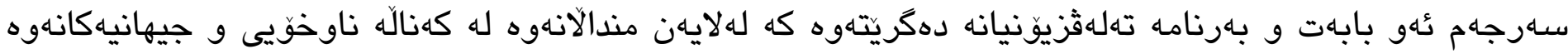

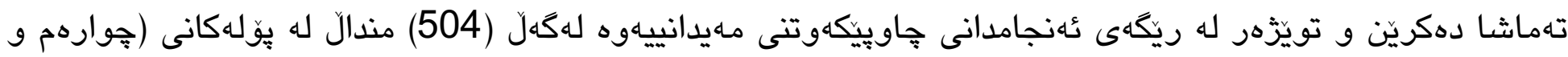

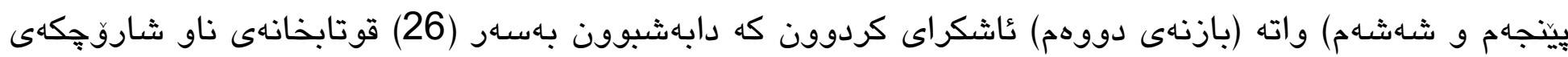
كوَيه بوّ سالخي خوينّني(2018-2019) .

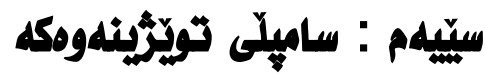

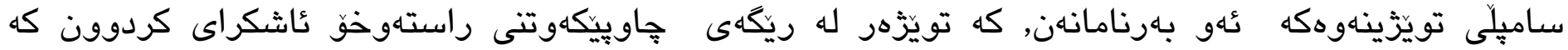

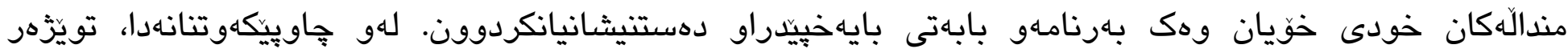


برسيارى ليكردوون كه (ئايا تهماشاى ع بهرنامهيهكى مندالآن دهكهيت؟). هـهر منداليّك ئازادبووه له وتنى زمارهى ئهو

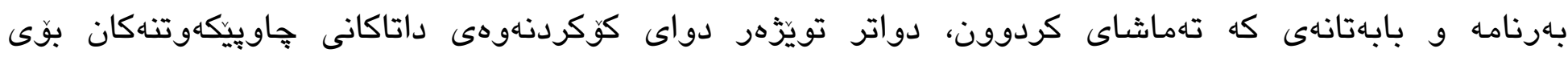

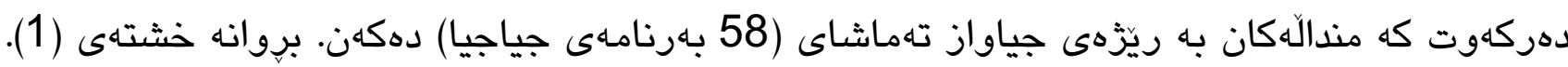

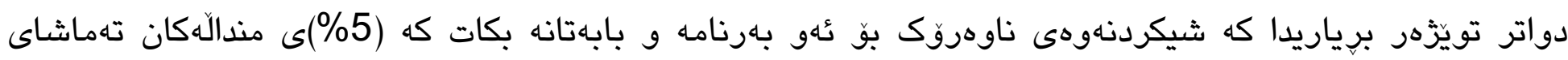

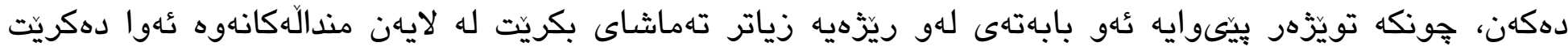

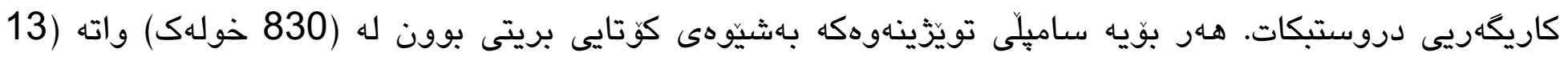

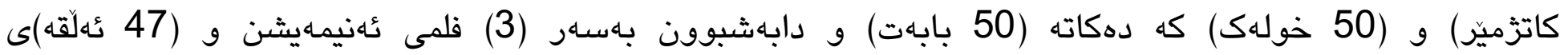

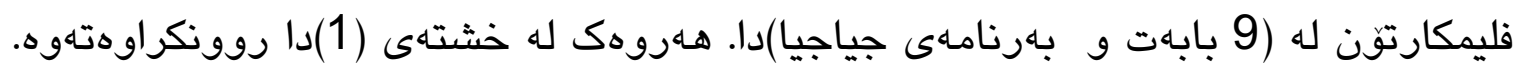

\section{خشتهى (1)}

خشتهى ساميلى تويّزينهوهك (1)

\begin{tabular}{|c|c|c|c|}
\hline $\begin{array}{c}\text { زمارهى } \\
\text { بهرامهكان }\end{array}$ & كاتى خايهنراو & شيكراوهكان & 3 \\
\hline ياك فلمى ئهنيمهيشن & $1: 49$ & frozen fانا و عالسا & \\
\hline يهك فلمى ئهنيمهيشن & $1: 42$ & 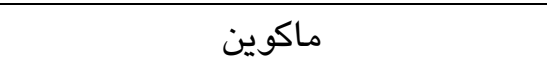 & 2 \\
\hline أ & $1: 34$ & سيايدهرمان & 3 \\
\hline 4 ئهلقه & $1: 32$ & سوقفيا & 4 \\
\hline 13 ئدلقه & 1:31 & Shaun the ship شوانى مهردكان & 5 \\
\hline 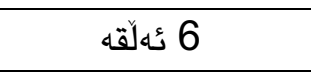 & $1: 30$ & سِيونج بوَب & 6 \\
\hline 12 ئلّهـ & $1: 29$ & توّم و جيرى & 7 \\
\hline 5 & $1: 28$ & Ben 10 & 8 \\
\hline يهك فليم كارتقن & 1:15 & سهندريلا & 9 \\
\hline 50 بهرنامه & 13:50 & كوى كثتى & \\
\hline
\end{tabular}

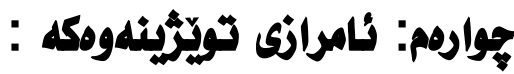

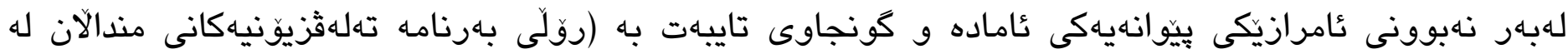

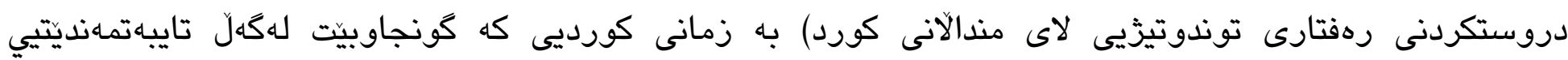

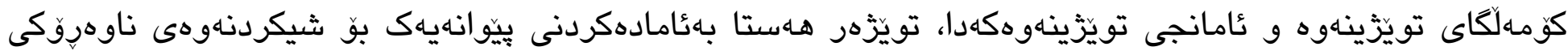

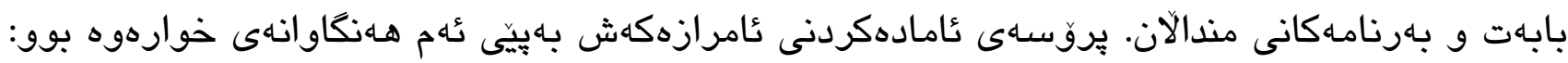

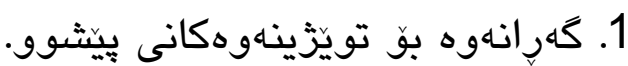




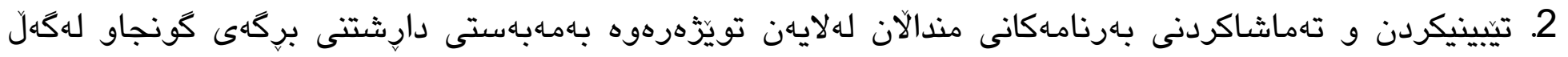

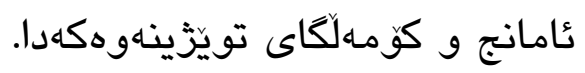

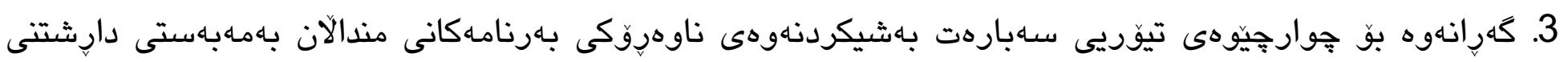

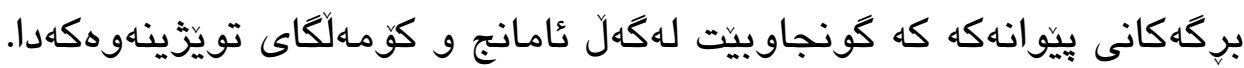

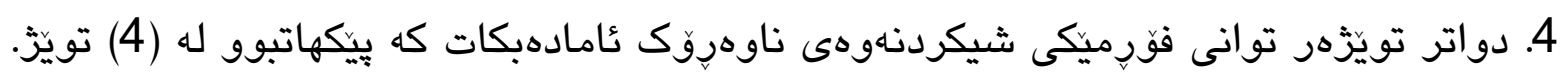

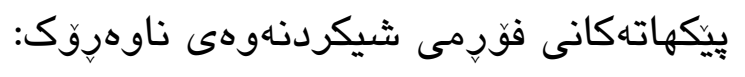

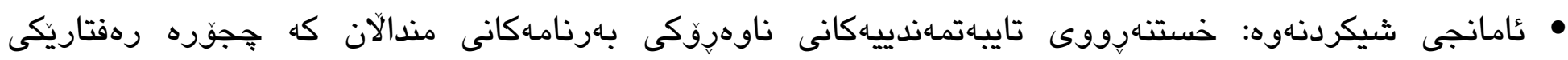
توندوتيزيى لهخو دهكريّت.

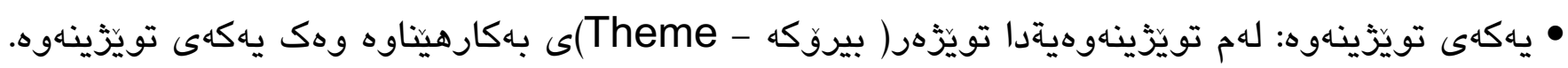

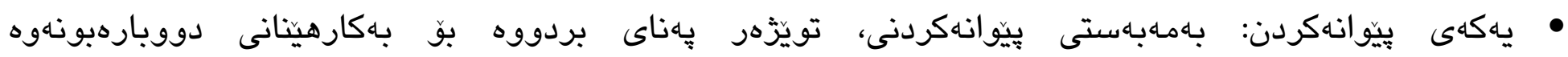

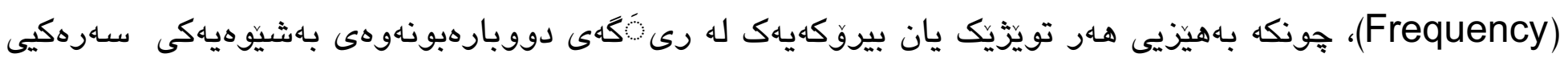

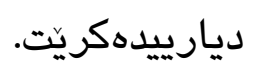

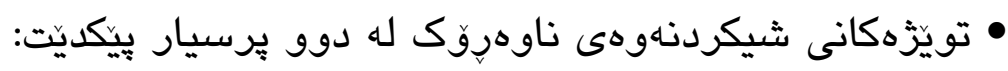

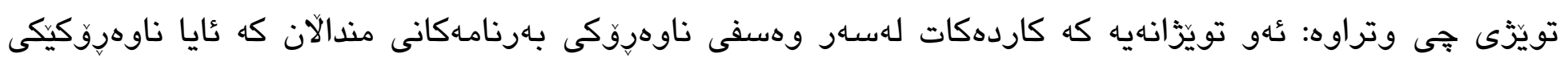
توندوتيزه يان توندوتيز نييه.

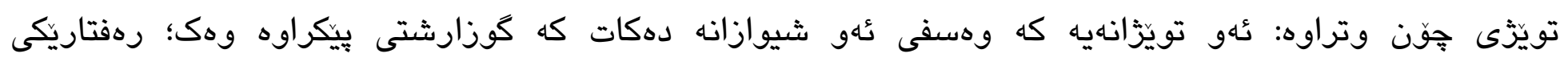

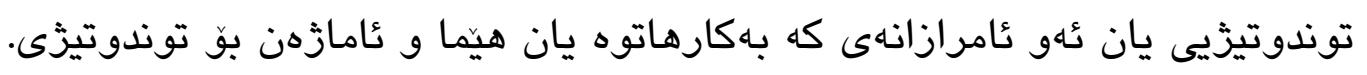




\section{بيّنجهم: دمستنيشافكردنى راستكويى بيّوانه:}

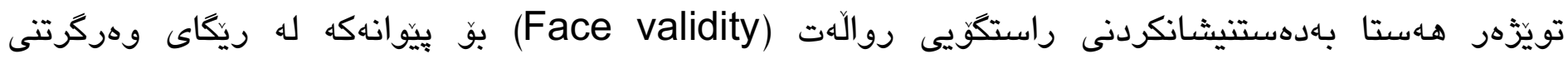

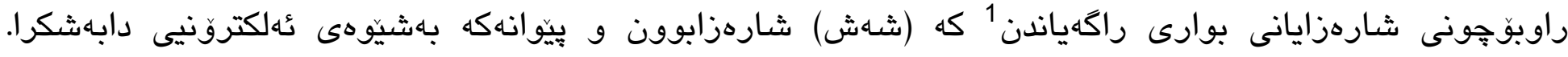

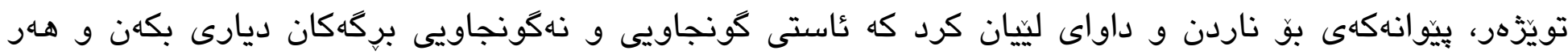

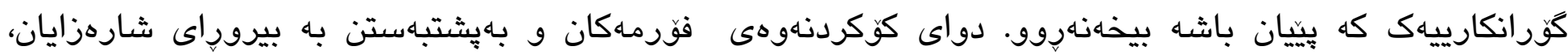

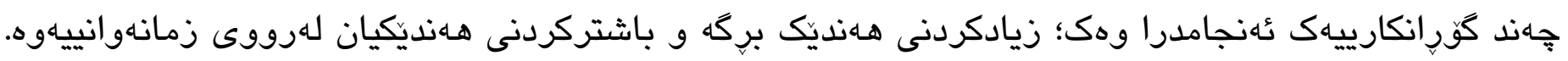

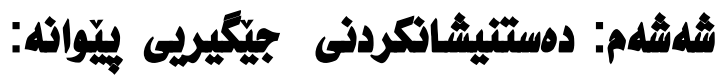

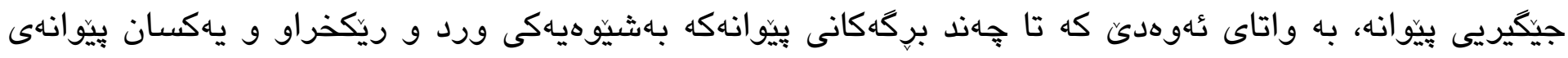

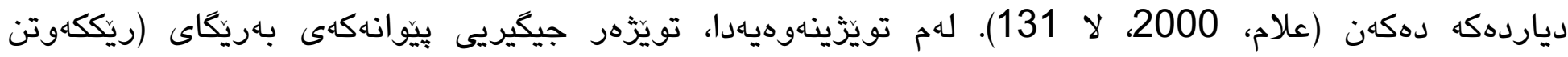

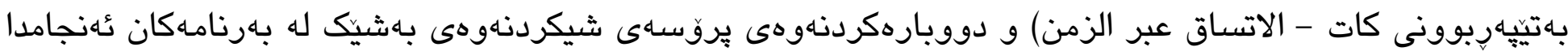

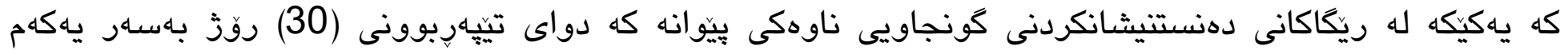

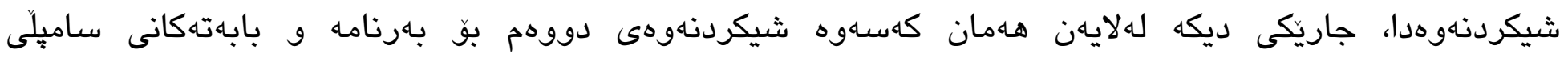
تويَزْينهوهكه ئهنجامدهدريّت

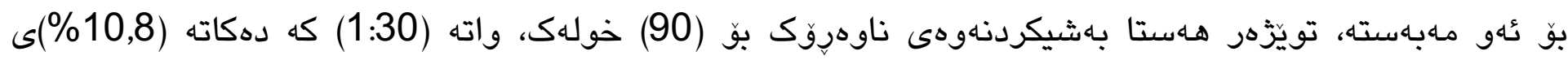

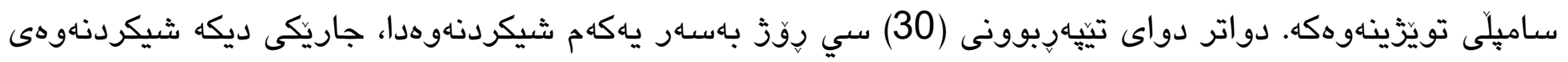

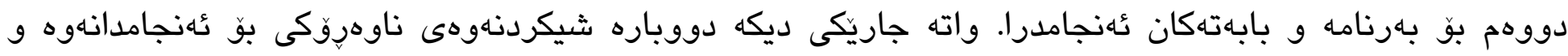

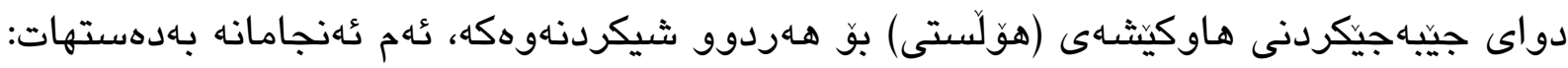

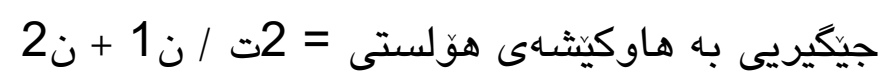

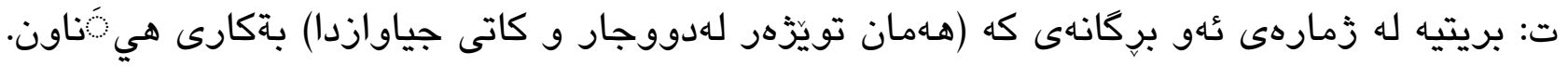

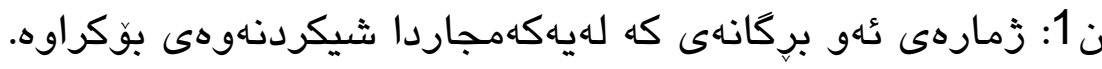

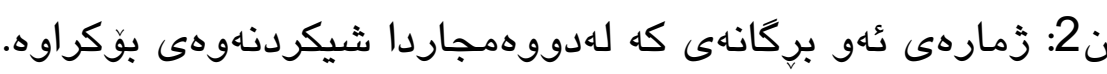

1 شارهزاكانى رااكهياندن بيكدين له هـريهك له :

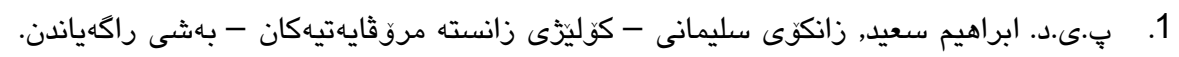

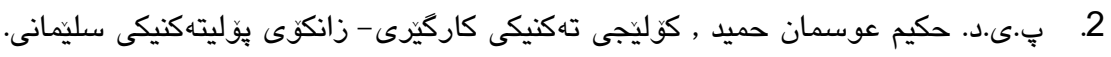

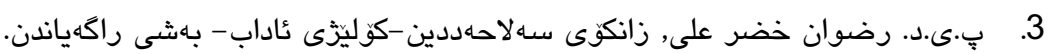

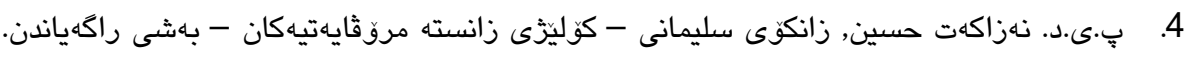

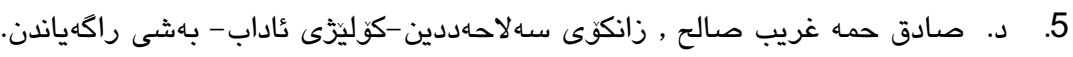

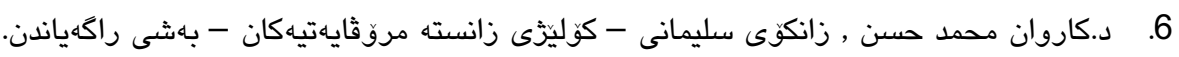
563 


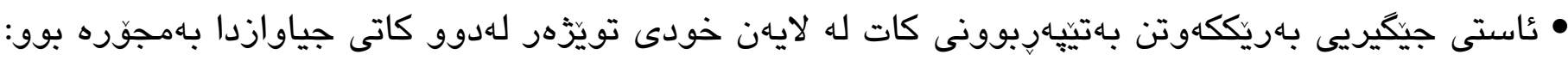

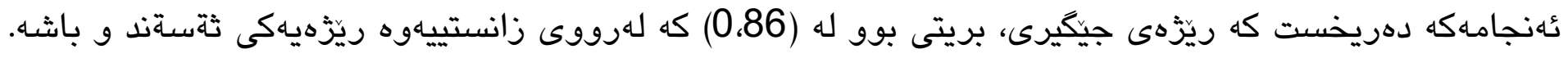

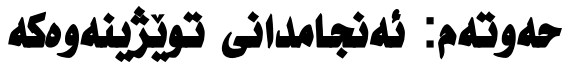

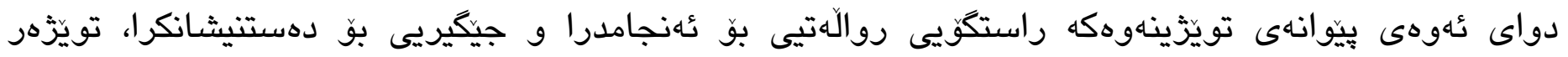

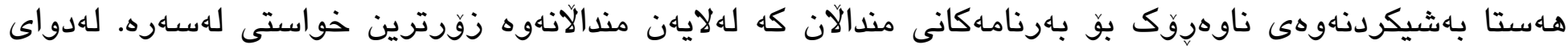

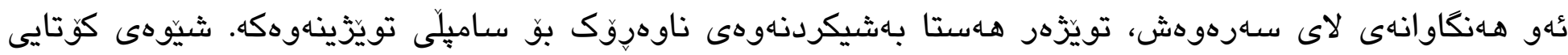

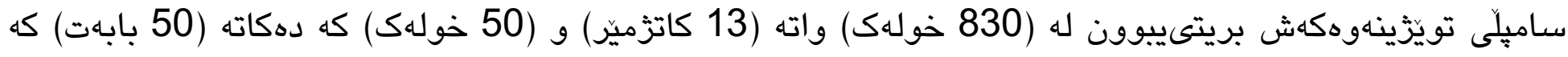

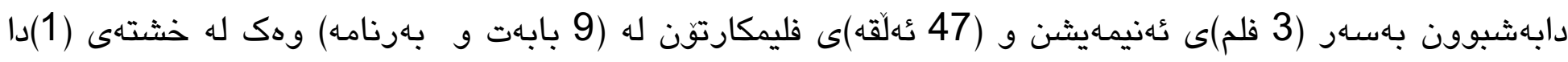
دوونكراونهتهوه.

\section{بلهُ هوارهم:

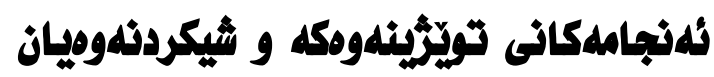

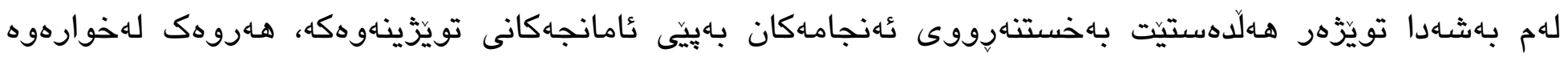
هاتووه:-

يلهكه: ئامانجى يهكه كه بريتى بوو له (ئاشكراكردن و خستنهوووى ئهو بهرنامه و بابهتانهى كه مندالهكان

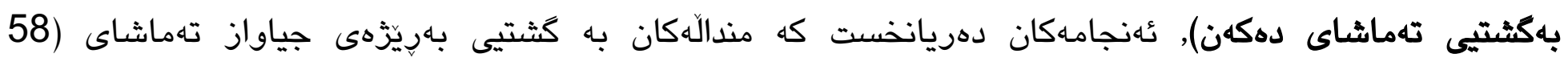

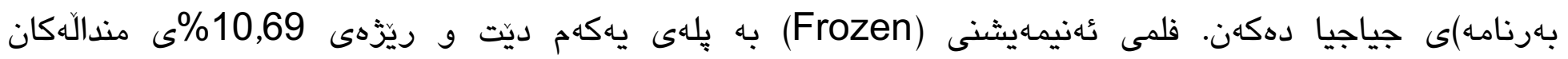

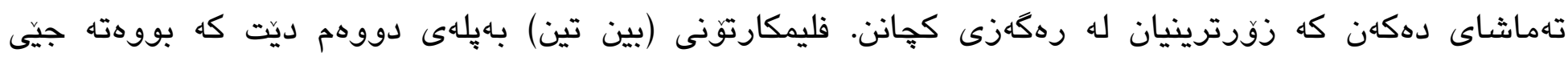

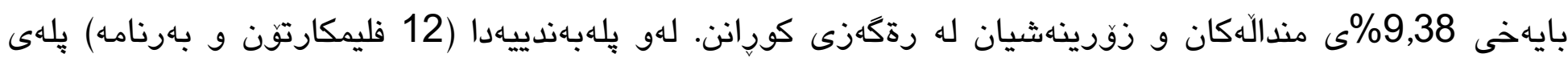

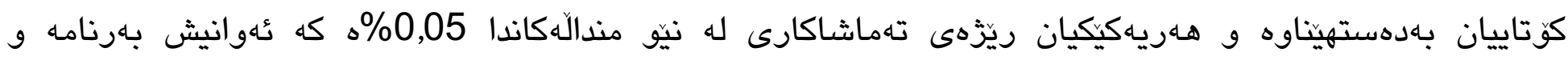




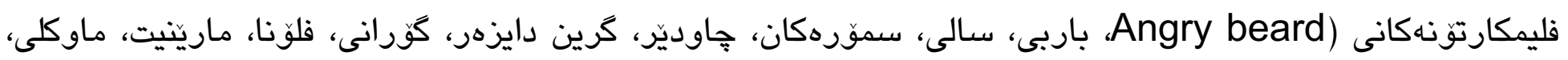
نيلز، هلوكيتى)يه، بروانه خشتهى (2).

خشتهى (2)

بهرنامه تهماثشاكراوهكان لهلايهن مندالهكانهوه بهكثتى

\begin{tabular}{|c|c|c|c|c|c|c|c|c|c|}
\hline \multirow{2}{*}{ سهيدّىى } & \multirow{2}{*}{ كنتى كنى } & \multicolumn{2}{|c|}{ يولى 6} & \multicolumn{2}{|c|}{ يوّلى 5} & \multicolumn{2}{|c|}{ يَّلى 4} & \multirow[t]{2}{*}{ بهرنامهكان } & \multirow[t]{2}{*}{ j } \\
\hline & & ك & كور & ك؟ & كور & كج & كور & & \\
\hline$\% 10,69$ & 179 & 68 & 1 & 54 & 3 & 52 & 1 & frozen & 1 \\
\hline$\% 9,38$ & 157 & 4 & 47 & - & 56 & 1 & 49 & Ben 10 & 2 \\
\hline$\% 9,20$ & 154 & 45 & 1 & 54 & 5 & 49 & --- & سوّفيا & 3 \\
\hline$\% 9,20$ & 154 & 23 & 21 & 23 & 35 & 22 & 30 & شوانى مهرهكان & 4 \\
\hline$\% 9,08$ & 152 & 47 & 1 & 43 & 6 & 51 & 4 & سهندريلا & 5 \\
\hline$\% 8,72$ & 146 & 1 & 37 & 2 & 53 & 6 & 47 & ماكوين & 6 \\
\hline$\% 7,59$ & 127 & 2 & 41 & -- & 42 & 2 & 40 & سيايدهرمان & 7 \\
\hline$\% 7,05$ & 118 & 18 & 20 & 10 & 27 & 19 & 24 & تقم و جيرى & 8 \\
\hline$\% 5,85$ & 98 & 13 & 23 & 10 & 27 & 7 & 18 & سيقِّنج بوَب & 9 \\
\hline$\% 3,64$ & 61 & 2 & 15 & --- & 23 & 2 & 19 & باتمان & 10 \\
\hline$\% 3,10$ & 52 & 18 & 2 & 12 & 2 & 18 & --- & دهنكه هـناره & \\
\hline$\% 1,61$ & 27 & 3 & 2 & 8 & 2 & 10 & 2 & ماشا & 12 \\
\hline$\% 1,19$ & 20 & 7 & -- & 7 & 1 & 5 & - & رديَّنزهل & 13 \\
\hline$\% 1,01$ & 17 & 5 & 1 & 4 & 2 & 5 & - & جيروّك & 14 \\
\hline$\% 0,95$ & 16 & 4 & 1 & 4 & 3 & 1 & 3 & Mr. Bean & 15 \\
\hline$\% 0,95$ & 16 & 5 & - & 3 & 1 & 7 & - & بيّياى بهراز & 16 \\
\hline$\% 0,83$ & 14 & 3 & 2 & 4 & 5 & -- & - & كايق & 17 \\
\hline$\% 0,77$ & 13 & 2 & 1 & 1 & 7 & 2 & - & شريك و فيوّنا & 18 \\
\hline$\% 0,65$ & 11 & 8 & - & 2 & - & 1 & - & بهارنامهى فيّركارى & 19 \\
\hline$\% 0,65$ & 11 & 1 & 4 & 1 & 3 & 1 & 1 & كلارينس & 20 \\
\hline$\% 0,47$ & 8 & 1 & 2 & - & 3 & 1 & 1 & ئاثاتار & 21 \\
\hline$\% 0,41$ & 7 & 1 & 1 & - & 5 & - & - & Alex & 22 \\
\hline$\% 0,41$ & 7 & 2 & 2 & - & - & 1 & 2 & Pink Panther & 23 \\
\hline$\% 0,41$ & 7 & 1 & 3 & - & 3 & - & - & T- Titans & 24 \\
\hline$\% 0,41$ & 7 & 1 & -- & 2 & - & 4 & -- & دوردا & 25 \\
\hline$\% 0,41$ & 7 & -- & 3 & --- & 3 & --- & 1 & سوِّهرمان & 26 \\
\hline$\% 0,41$ & 7 & 3 & 2 & - & 1 & 1 & -- & سيّ ورجهـكه & 27 \\
\hline$\% 0,41$ & 7 & 3 & 1 & 2 & 1 & --- & -- & مشكو & 28 \\
\hline$\% 0,41$ & 7 & - & 2 & - & 1 & 2 & 2 & ل & 29 \\
\hline$\% 0,35$ & 6 & - & 3 & - & 2 & 1 & - & كامبوّل & 30 \\
\hline$\% 0,35$ & 6 & 2 & 1 & - & -- & 3 & - & ميكى ماوس & 31 \\
\hline
\end{tabular}




\begin{tabular}{|c|c|c|c|c|c|c|c|c|c|}
\hline$\% 0,29$ & 5 & - & 1 & 1 & 2 & 1 & - & تايو & 32 \\
\hline$\% 0,29$ & 5 & 2 & 1 & - & - & 2 & - & سهنفورهكان & 33 \\
\hline$\% 0,29$ & 5 & & 1 & - & 2 & 1 & 1 & عهدنان و لينا & 34 \\
\hline$\% 0,17$ & 3 & - & - & 1 & - & 2 & - & فيّربونى زمان بان & 35 \\
\hline$\% 0,17$ & 3 & - & 2 & - & 1 & - & - & تهرهزان & 36 \\
\hline$\% 0,17$ & 3 & - & 2 & - & 1 & - & - & العم جدو & 37 \\
\hline$\% 0,11$ & 2 & - & - & 1 & - & 1 & - & بيلّلى & 38 \\
\hline$\% 0,11$ & 2 & - & - & -- & 2 & - & - & توم سويّر & 39 \\
\hline$\% 0,11$ & 2 & - & - & 2 & - & - & - & دهنكه خَّل & 40 \\
\hline$\% 0,11$ & 2 & 1 & - & - & - & - & 1 & روّرى & 41 \\
\hline$\% 0,11$ & 2 & - & - & - & - & - & 2 & زازى & 42 \\
\hline$\% 0,11$ & 2 & - & - & - & 1 & - & 1 & كوَنقو ياندا & 43 \\
\hline$\% 0,11$ & 2 & - & - & - & - & 2 & - & نهينيهكتنى جوجو & 44 \\
\hline$\% 0,11$ & 2 & 1 & - & 1 & - & - & - & هايدى & 45 \\
\hline$\% 0,11$ & 2 & - & 1 & - & - & - & 1 & ئهنجلو & 46 \\
\hline$\% 0,05$ & 1 & - & 1 & - & - & - & - & Angry beard & 47 \\
\hline$\% 0,05$ & 1 & 1 & - & - & - & - & - & باربى & 48 \\
\hline$\% 0,05$ & 1 & - & - & 1 & - & - & - & سالى & 49 \\
\hline$\% 0,05$ & 1 & - & - & 1 & - & - & - & سموّرهكان & 50 \\
\hline$\% 0,05$ & 1 & - & - & - & - & - & 1 & جاوديّر & 51 \\
\hline$\% 0,05$ & 1 & - & 1 & - & - & - & - & كرين دايزهر & 52 \\
\hline$\% 0,05$ & 1 & - & - & - & - & 1 & - & كُّرانى & 53 \\
\hline$\% 0,05$ & 1 & 1 & - & - & - & - & - & فلوّنا & 54 \\
\hline$\% 0,05$ & 1 & 1 & - & - & - & - & - & مارينيتيت & 55 \\
\hline$\% 0,05$ & 1 & - & - & - & - & - & 1 & ماوكلى & 56 \\
\hline$\% 0,05$ & 1 & - & - & - & - & - & 1 & نيلز & 57 \\
\hline$\% 0,05$ & 1 & - & - & - & - & 1 & -- & هلو كيتى & 58 \\
\hline$\% 100$ & 1673 & 300 & 250 & 254 & 331 & 285 & 253 & كوى كشتى & \\
\hline
\end{tabular}


دووهم: عامانجى دووهم كه بريتي بوو لـ(شيكردنهوهى ناوهروكى ثئو بهرنامه و بابهتانهى كه زورترين بينهرى هـهيه

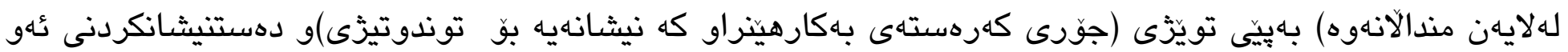
بهرنامانهى كه زورترين جار دووبارهبونهوهى لهمجوره توندوتيزيهدا هـيهو دهستنيشانكردن و يلهبهندكردنى ئهو بركَكانهى كه زورترين دووباره بوونهوه و ريَزهى لهم تويَّزها بـهدستهيناوه، دهركهوت كه فليمكارتونى (سيايدهرمان) بهايلهى يـكهم ديّت لهبهكارهينانى كهرهسته و كردارى توندوتيزّييدا كه (67 جار) كهرهستهى

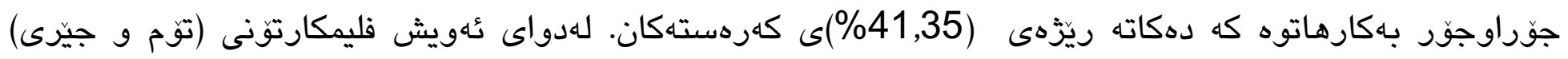
بهايلهى دووهم ديّت كه تيايدا (46 جار) كهرهسته بهكارهاتوه كه دهاته ريّزهى (28,39\%)ى كهرهسته

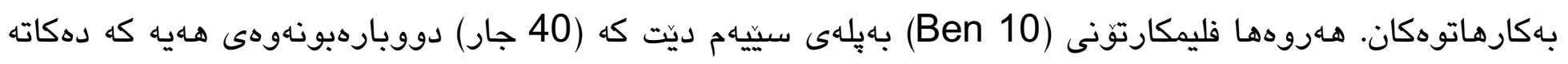

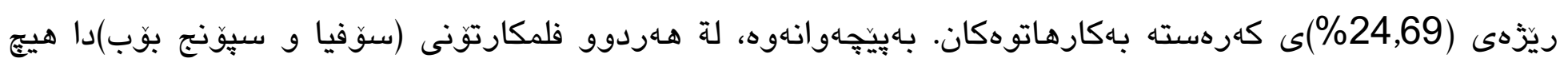
جوره كهرهستهيهكى تايبهت به توندوتيزّيى بهكارنهاتووه.

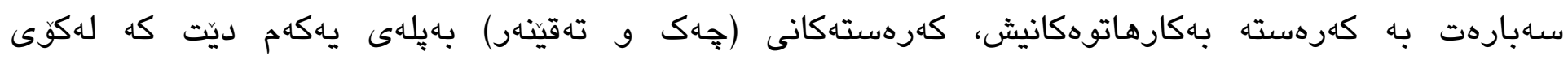

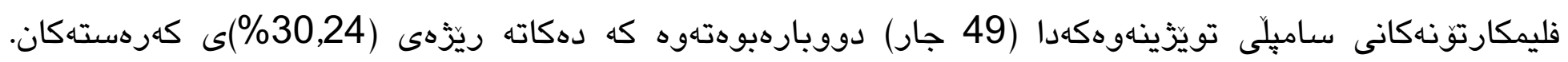
كهرهستهى (ئاكر و تيشك) بهيلهى دووهم ديّت كه (39 جار) دووباره بووهتهوه كه دهكاته ريزّهى (24,07\%)ى كهرهسته بـكارهاتوهكان. كهرهستهى (رهق و توند) يلهى سينيهمى بـدهستهيناوه و (22 جار) دووبارهبووهتهوه كه دهكاته ريّزهى (13,58\%)ى كهرهستهكان. كهرهستهانى (بهرد و خشت)دوا يلهيان بهدهستيهيناوه كه تهنها (5 جار)

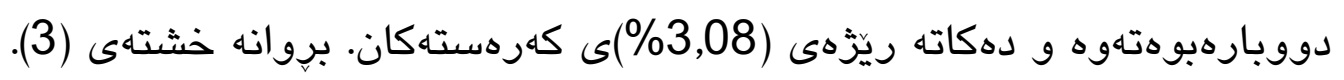


خشتهى (3) بكار هنر (3)

تويّزى جوّرى كهرهستهى بهكارهينراو كه نيشانهيه بو توندوتيزّى

\begin{tabular}{|c|c|c|c|c|c|c|c|c|c|c|c|c|}
\hline $\begin{array}{c}3 \\
3 \\
3 \\
y \\
3 \\
3 \\
3 \\
y\end{array}$ & $\begin{array}{l}\text { y } \\
\text { y } \\
\text { : }\end{array}$ & 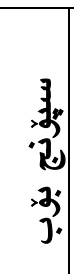 & $\begin{array}{l}32 \\
2 \\
9 \\
4 ; \\
3\end{array}$ & $\begin{array}{l}3.3 \\
3: \\
3 \\
3 \\
3 \\
0\end{array}$ & $\begin{array}{l}\text { जे } \\
\text {.3 }\end{array}$ & 勇 & $\begin{array}{l}\frac{4}{13} \\
\frac{9}{9} \\
y^{2} \\
\frac{1}{3}\end{array}$ & 量。 & $\begin{array}{l}\text { 우 } \\
\Phi \\
\Phi \\
\Phi\end{array}$ & $\begin{array}{l}\stackrel{ }{\Phi} \\
\stackrel{N}{2}\end{array}$ & بهارهنينزاو بونى & \\
\hline $\begin{array}{c}30,24 \\
\%\end{array}$ & 49 & - & 9 & 28 & - & - & - & - & 12 & - & جهـك و تهقينها & 1 \\
\hline $\begin{array}{c}24,07 \\
\%\end{array}$ & 39 & - & 4 & 19 & - & - & - & - & 16 & -- & عاكر و تيشك & 2 \\
\hline $\begin{array}{c}13,58 \\
\%\end{array}$ & 22 & - & 11 & 6 & -- & 1 & 1 & - & 2 & 1 & كهردستهى ردق & 3 \\
\hline $\begin{array}{c}12,34 \\
\%\end{array}$ & 20 & - & 5 & 7 & 1 & - & - & - & 4 & 3 & دروستكراوى تر & 4 \\
\hline$\% 4,93$ & 8 & - & 3 & 4 & - & - & 1 & - & -- & - & جִهق و جָهتال & 5 \\
\hline$\% 4,32$ & 7 & - & 2 & - & - & - & 1 & - & 4 & - & دار & 6 \\
\hline$\% 3,70$ & 6 & - & 6 & -- & - & - & - & - & -- & - & لهֶם & 7 \\
\hline$\% 3,70$ & 6 & - & 6 & -- & - & - & - & - & -- & - & قرتينهر وهك مقهت & 8 \\
\hline \multirow[t]{2}{*}{$\% 3,08$} & 5 & - & -- & 3 & - & - & - & - & 2 & - & بهرد و خشت & 9 \\
\hline & $\begin{array}{c}16 \\
2\end{array}$ & - & 46 & 67 & 1 & 1 & 3 & - & 40 & 4 & كؤى كثتى & \\
\hline$\% 100$ & & $\begin{array}{c}0 \\
\%\end{array}$ & $\begin{array}{l}28,3 \\
\% 9\end{array}$ & $\begin{array}{l}41,3 \\
\% 5\end{array}$ & $\begin{array}{c}0,61 \\
\%\end{array}$ & $\begin{array}{l}0,6 \\
\% 1\end{array}$ & $\begin{array}{c}1,85 \\
\%\end{array}$ & $\begin{array}{l}0 \\
\%\end{array}$ & $\begin{array}{c}24,69 \\
\%\end{array}$ & $\% 2,46$ & ريّزّهى سهدى & \\
\hline
\end{tabular}




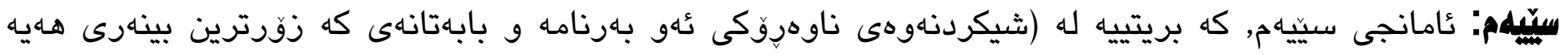
للهلايهن مندالانهوه, بـيِيَى تويَّىى (توندوتيزيى وتراو) و دهستيشانكردنى ئهو بهرنامانهى كه زورترين جار

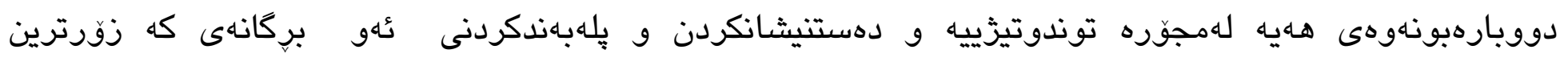

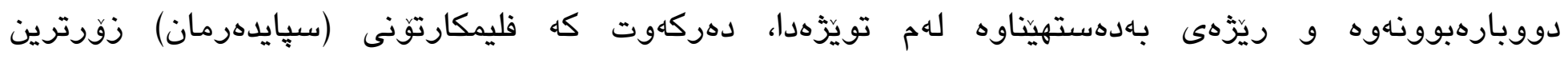

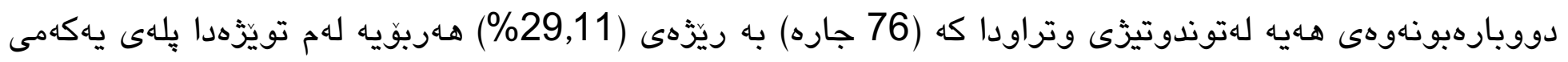
بهدهستهيناوه. فليمكارتّنى (Ben 10)يش بهيلهى دووهم ديّت كه بركَكانى ئهم تويّزه (62 جار) دووياره بووهتهوه كه دهكاته ريّزهى (23,76\%). فليمكارتونى (توّم و جيّر) بهيلهى سيّيهم ديّت كه (44 جار) دووباره بوونهوهى هـهيه

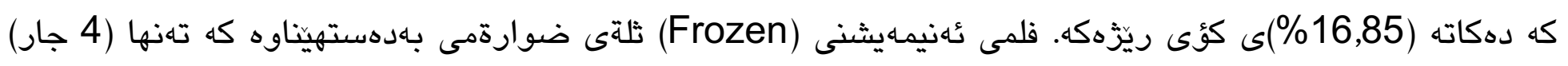

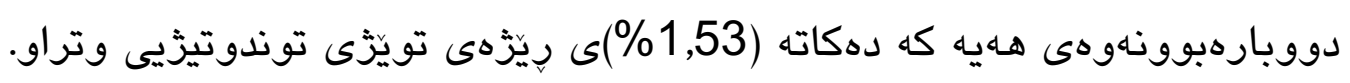

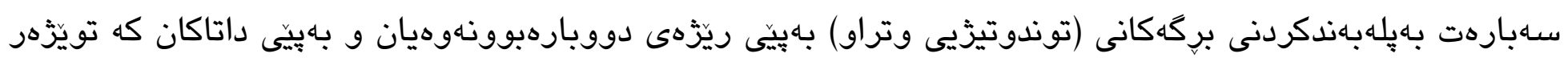

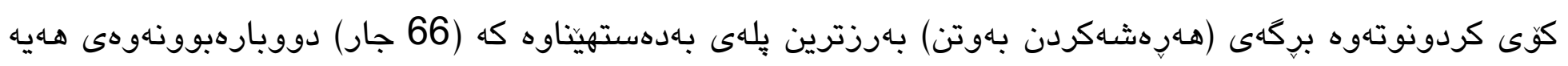

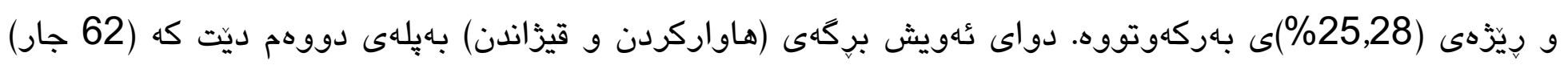

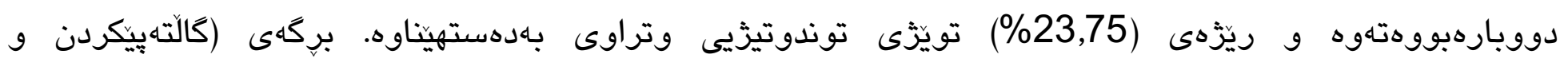
رووشكاندن - اهانة)يش بهيلهى سيّيهم ديّت و (54 جار) دووبارهبوونهوهى هـيه كه دهكاته (20,68\%)ى ريّزهى تويّزى توندوتيزيى وتراو. برِكى (دهربرينى رق بهزارهيى و بهنووسين) به دوا پِلهى دين كه تهنها (21 جار)

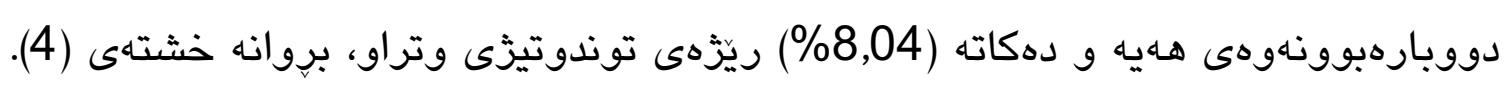


خشتهى (4)

خشتهى تويَّى توندوتيزيى وتراو

\begin{tabular}{|c|c|c|c|c|c|c|c|c|c|c|c|c|}
\hline $\begin{array}{l}x_{3}^{3} \\
y^{3} \\
3 \\
3 \\
3\end{array}$ & $\begin{array}{l}y \\
y \\
y \\
3\end{array}$ & 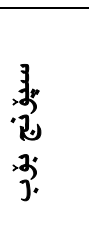 & $\begin{array}{l}3 \\
2 \\
9 \\
3 \\
3\end{array}$ & 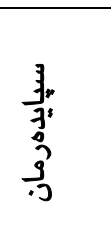 & $\begin{array}{l}3 \\
\text { bे } \\
.3\end{array}$ & 晃 & $\begin{array}{l}\frac{3}{3} \\
\frac{3}{3} \\
\frac{9}{3} \\
\frac{0}{3}\end{array}$ & 预, & 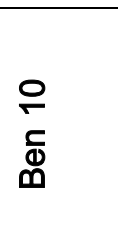 & $\begin{array}{l}\text { @ } \\
\text { N̦ }\end{array}$ & توندوتيزيى & j \\
\hline$\% 25,28$ & 66 & - & 5 & 23 & 2 & 2 & -- & 1 & 33 & -- & هـردشهكردن به & 1 \\
\hline$\% 23,75$ & 62 & - & 19 & 23 & 1 & 7 & 3 & 3 & 4 & 2 & هاواركردن و قيزّاندن & 2 \\
\hline$\% 20,68$ & 54 & - & 14 & 7 & 10 & 4 & 6 & 3 & 10 & -- & 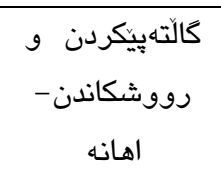 & 3 \\
\hline$\% 9,96$ & 26 & 9 & 2 & 5 & - & 2 & - & 5 & 1 & 2 & 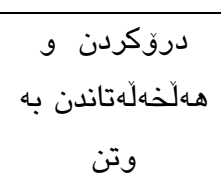 & 4 \\
\hline$\% 8,81$ & 32 & 6 & 1 & 9 & - & 7 & - & - & 9 & - & جناوناتودران و & 5 \\
\hline$\% 8,04$ & 21 & - & 3 & 9 & - & 2 & - & 2 & 5 & - & زارهكى و نوسينى دق به & 6 \\
\hline & 261 & 15 & 44 & 76 & 13 & 24 & 9 & 14 & 62 & 4 & كو ى كثتى & \\
\hline$\% 100$ & & $\begin{array}{c}5,74 \\
\%\end{array}$ & $\begin{array}{c}16,85 \\
\%\end{array}$ & $\begin{array}{c}29,11 \\
\%\end{array}$ & $\begin{array}{c}4,98 \\
\%\end{array}$ & $\begin{array}{c}9,19 \\
\%\end{array}$ & $\begin{array}{c}3,44 \\
\%\end{array}$ & $\begin{array}{c}5,36 \\
\%\end{array}$ & $\begin{array}{c}23,76 \\
\%\end{array}$ & $\begin{array}{c}1,53 \\
\%\end{array}$ & & \\
\hline
\end{tabular}

هوارهم: ئامانجى جوارهم كه بريتيه له (شيكردنهوهى ناوهروكى ئهو بهرنامه و بابهتانهى كه زورترين بينهرى هـهاه لهلايهن

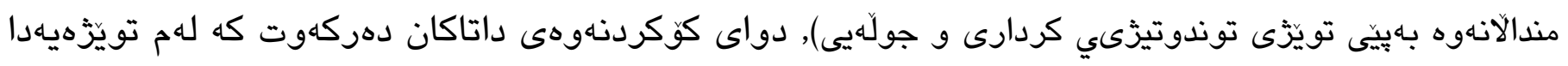

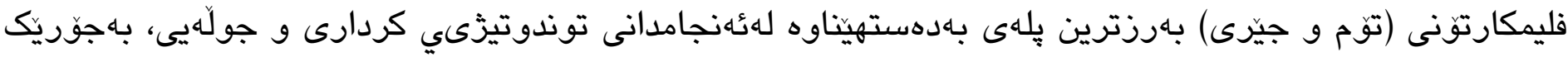

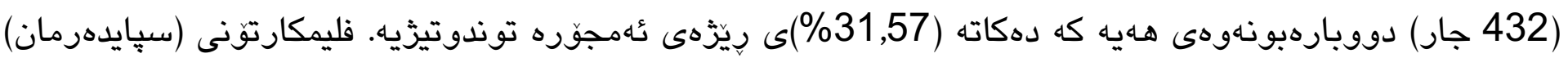

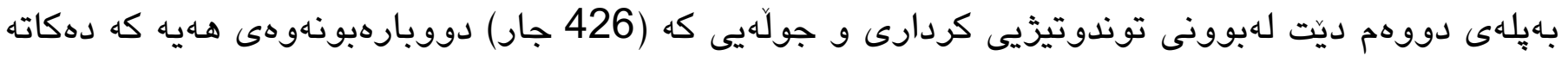

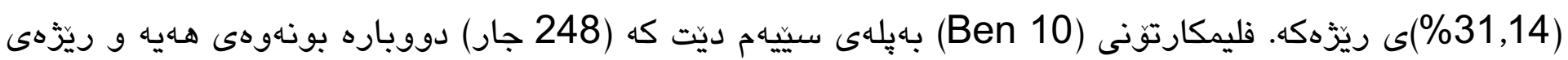

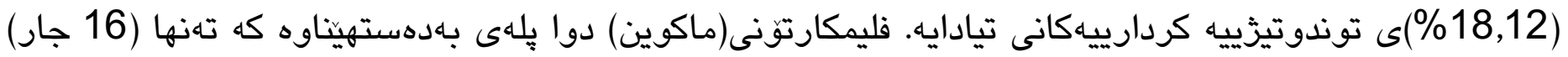

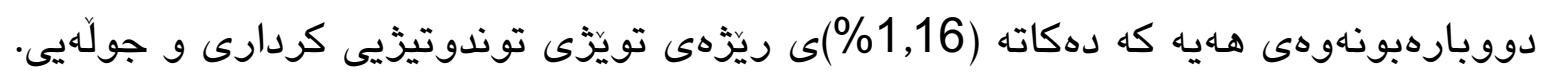




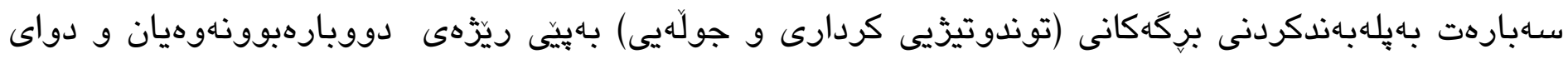

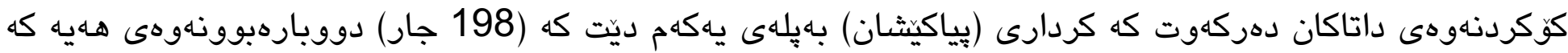

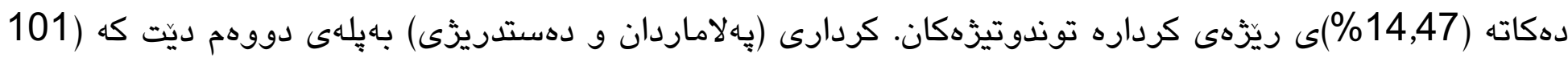

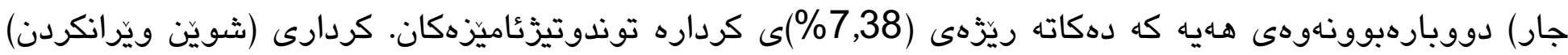

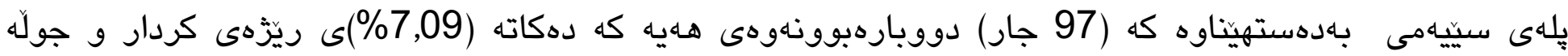

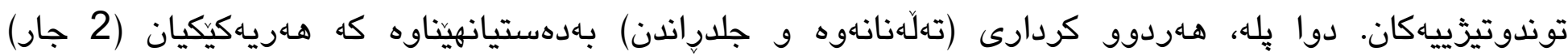
دووبارهبوونهوهيان هايه كه دهكاته (0,14\%)ى ريّزّى كرداره توندوتيزييهكان، برِوانه خشتهى (5).

خشتهى (5)

خشتهى تويّزى توندوتيزّيى كردارى و جولَهيى

\begin{tabular}{|c|c|c|c|c|c|c|c|c|c|c|c|c|}
\hline $\begin{array}{l}a_{3}^{3} \\
\dot{3} \\
y \\
3 \\
y\end{array}$ & $\begin{array}{l}y \\
y \\
y \\
3\end{array}$ & $\begin{array}{l}3.3 \\
3 \\
3 \\
3.2\end{array}$ & $\begin{array}{l}32 \\
2 \\
9 \\
4 \\
3 \\
3\end{array}$ & $\begin{array}{l}3 . \\
3 . \\
3: \\
3 \\
3 \\
.0\end{array}$ & $\begin{array}{l}3 \\
.3 \\
.3\end{array}$ & 埥 & $\begin{array}{l}\frac{4}{3} \\
\frac{3}{3} \\
9 \\
0 \\
\frac{9}{3}\end{array}$ & 严, & 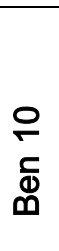 & 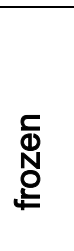 & توندوتيزيّ & $j$ \\
\hline$\% 14,47$ & 198 & 18 & 63 & 40 & 7 & 5 & 8 & & 55 & 2 & بياكيثـان & 1 \\
\hline$\% 7,38$ & 101 & 1 & 23 & 51 & 3 & 3 & 3 & - & 17 & - & "ِهلاماردان و & 2 \\
\hline$\% 7,09$ & 97 & 11 & 22 & 40 & - & - & 6 & 3 & 13 & 2 & شويّن ويِرانكردن & 3 \\
\hline$\% 6,72$ & 92 & 6 & 51 & 14 & - & 3 & 3 & 2 & 11 & 2 & ي باونان & 4 \\
\hline$\% 5,40$ & 74 & 5 & 17 & 31 & - & 2 & 6 & 6 & 7 & - & شتشكاندن & 5 \\
\hline$\% 4,97$ & 68 & - & 5 & 43 & - & - & - & - & 20 & - & هـولَّ كوشتن و & 6 \\
\hline$\% 3,58$ & 49 & - & - & 28 & - & - & - & - & 21 & - & عاكرتيكرتن & 7 \\
\hline$\% 3,28$ & 45 & 2 & 30 & 8 & -- & 2 & - & 2 & - & 1 & هـلَّهلّة داندن ون & 8 \\
\hline$\% 3,07$ & 42 & 1 & 26 & 14 & - & - & - & - & 1 & - & توّلَهسهندنهوه به & 9 \\
\hline$\% 2,99$ & 41 & 5 & 21 & 5 & - & 2 & 6 & - & - & 2 & هان لدانهدهرهوه & 10 \\
\hline
\end{tabular}




\begin{tabular}{|c|c|c|c|c|c|c|c|c|c|c|c|c|}
\hline$\% 2,92$ & 40 & 2 & 21 & -- & - & 3 & 5 & 2 & 7 & - & 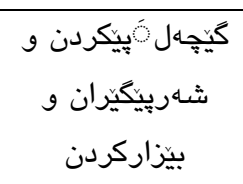 & 11 \\
\hline$\% 2,70$ & 37 & 1 & 4 & 17 & - & - & - & - & 15 & - & تهقاندنهوه & 12 \\
\hline$\% 2,55$ & 35 & 3 & 9 & 6 & - & 1 & 4 & 2 & 8 & 2 & راكيثان & 13 \\
\hline$\% 2,48$ & 34 & - & 10 & 16 & - & 1 & - & - & 7 & - & شـهليّان & 14 \\
\hline$\% 2,41$ & 33 & 4 & 16 & - & - & 2 & 5 & 3 & 3 & -- & دزيتكرتن و رفانسن و & 15 \\
\hline$\% 2,33$ & 32 & 1 & 10 & 14 & - & - & - & - & 7 & - & بياجهةقاندن & 16 \\
\hline$\% 2,33$ & 32 & 2 & - & 14 & - & 2 & - & 4 & 8 & 2 & هـلَّلَّردن و & 17 \\
\hline$\% 2,26$ & 31 & - & 4 & 14 & 1 & 2 & 2 & - & 8 & - & بِالَّان & 18 \\
\hline$\% 2,04$ & 28 & & 6 & 18 & - & - & - & - & 3 & 1 & زللهليّان & 19 \\
\hline$\% 1,97$ & 27 & - & 7 & 7 & 1 & 1 & - & 2 & 8 & 1 & بهاندكردن و دهركا & 20 \\
\hline$\% 1,82$ & 25 & 1 & 12 & - & - & - & 3 & -- & 7 & 2 & هـلَّانهخواردوه & 21 \\
\hline$\% 1,68$ & 23 & 1 & 10 & 5 & - & 2 & 2 & 3 & - & - & بو بِيلاندانان & 22 \\
\hline$\% 1,38$ & 19 & - & 6 & 11 & - & - & 2 & - & - & - & به بهاتكرتن و & 23 \\
\hline$\% 1,09$ & 15 & -- & 1 & 3 & 3 & 2 & - & - & 6 & - & خُوبه كَوردزانين & 24 \\
\hline$\% 1,09$ & 15 & 1 & 6 & 3 & - & - & - & - & 4 & 1 & هـلَّانه ناو ئاو & 25 \\
\hline$\% 0,80$ & 11 & 1 & 6 & & - & 2 & 1 & 1 & - & - & ريُليكرتن & 26 \\
\hline$\% 0,80$ & 11 & 2 & 1 & 5 & - & - & 3 & - & - & - & سيخورييكردن & 27 \\
\hline$\% 0,73$ & 10 & -- & 4 & - & - & - & - & - & 6 & - & 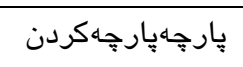 & 28 \\
\hline$\% 0,73$ & 10 & 2 & 4 & 4 & - & - & - & - & - & - & قهيليكَرتن & 29 \\
\hline$\% 0,73$ & 10 & - & - & 9 & - & - & 1 & - & - & - & هـهرهشه به جوله & 30 \\
\hline$\% 0,73$ & 10 & 2 & 2 & -- & 1 & 1 & 4 & - & - & - & يان يانتر يِيسكردن & 31 \\
\hline
\end{tabular}




\begin{tabular}{|c|c|c|c|c|c|c|c|c|c|c|c|c|}
\hline$\% 0,65$ & 9 & - & 5 & -- & - & 2 & 1 & -- & 1 & - & هـهولدان بو خواردنى & 32 \\
\hline$\% 0,43$ & 6 & - & 6 & - & - & - & - & - & - & - & برينداركردن و ييّست & 33 \\
\hline$\% 3,58$ & 6 & 49 & 7 & 19 & 6 & & 2 & 9 & 5 & 1 & ترساندن & 34 \\
\hline$\% 0,21$ & 3 & - & 1 & & - & - & 2 & - & - & - & شتدرباندن & 35 \\
\hline$\% 0,14$ & 2 & -- & 2 & - & - & - & - & - & - & - & تهلة تانهاوه & 36 \\
\hline$\% 0,14$ & 2 & - & - & - & - & 2 & - & - & - & - & جل دراندن & 37 \\
\hline \multirow[t]{3}{*}{$\% 0,14$} & 2 & - & 2 & - & - & - & - & - & - & - & هـالّواسين & 38 \\
\hline & 1368 & 79 & 432 & 426 & 16 & 42 & 76 & 30 & 248 & 19 & كوى كثتى & \\
\hline & & $\% 5,77$ & $\begin{array}{c}31,57 \\
\%\end{array}$ & $\begin{array}{c}31,14 \\
\%\end{array}$ & $\% 1,16$ & $\% 3,07$ & $\% 5,55$ & $\% 2,19$ & $\begin{array}{l}18,1 \\
\% 2\end{array}$ & $\% 1,38$ & ريّزهى سهادى & \\
\hline
\end{tabular}

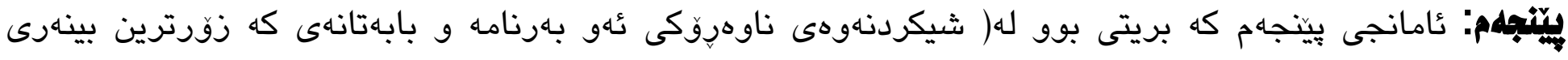

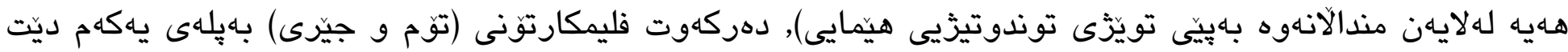

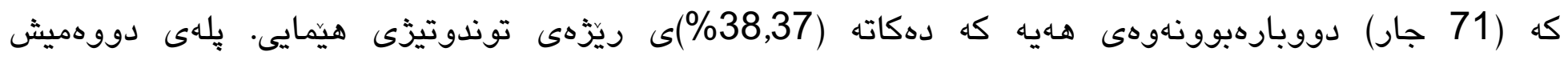

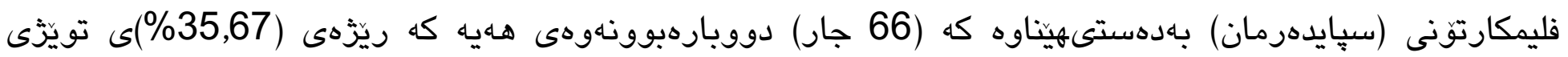

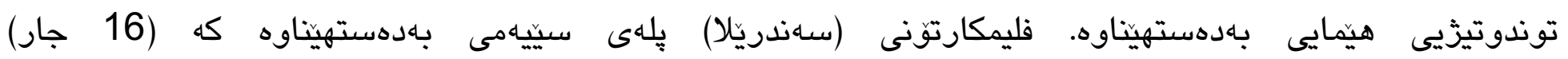

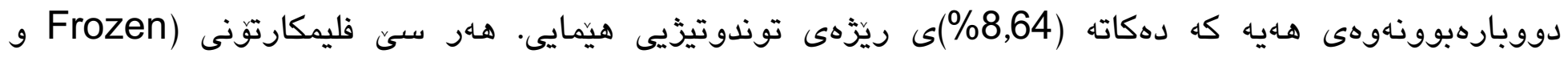

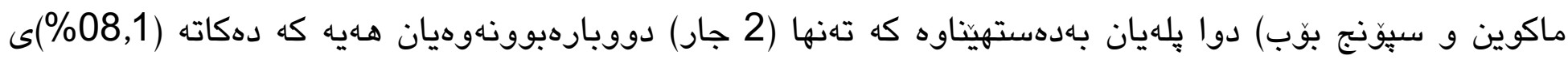
ريّزَهى توندوتيزييه هيماييهكان.

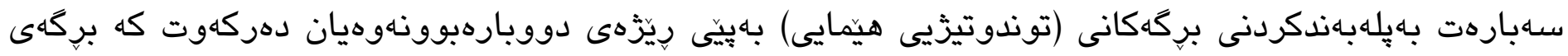

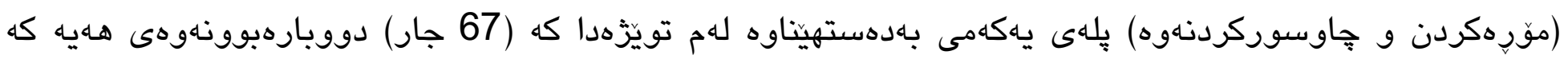

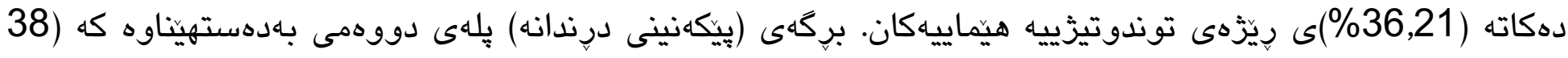

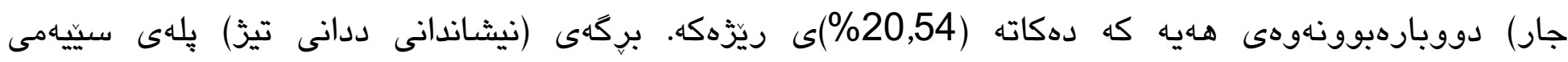

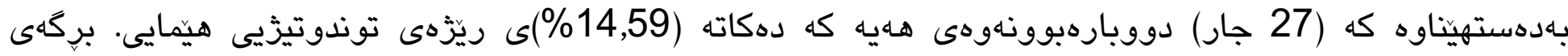

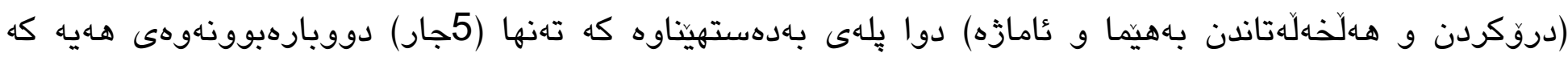

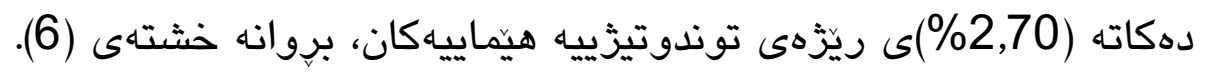




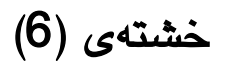

خشتهى توندوتيزيى هيمايى

\begin{tabular}{|c|c|c|c|c|c|c|c|c|c|c|c|c|}
\hline $\begin{array}{l}3 \\
3 \\
y \\
3 \\
3 \\
3 \\
3\end{array}$ & $\begin{array}{l}y \\
y \\
y \\
\text { y. }\end{array}$ & 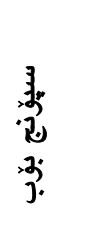 & $\begin{array}{l}3 \\
2 \\
9 \\
3 \\
3 \\
3\end{array}$ & 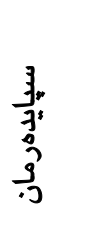 & $\begin{array}{l}\overrightarrow{3} \\
\text { 3. } \\
\text { 3. }\end{array}$ & 㝵 & $\begin{array}{l}\frac{3}{3} \\
\frac{3}{3} \\
9 \\
\hat{y}^{2} \\
\frac{3}{3}\end{array}$ & 㝵, & 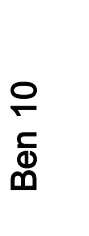 & 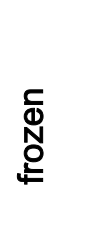 & توندوتيزيى هيمايى & $j$ \\
\hline$\% 36,21$ & 67 & - & 38 & 13 & 2 & 5 & 5 & 3 & - & 1 & جوّوردكردن و & 4 \\
\hline$\% 20,54$ & 38 & 1 & 11 & 15 & - & 2 & 1 & 2 & 6 & - & بيكيكنينى دريندانه & 1 \\
\hline$\% 14,59$ & 27 & - & 9 & 16 & - & 2 & - & - & - & - & نيشاندانى ددانى تيز & 6 \\
\hline$\% 10,81$ & 20 & - & 4 & 11 & - & - & - & - & 5 & - & تواناى ماسولكه و جهسته & 5 \\
\hline$\% 7,02$ & 13 & - & - & 11 & - & 2 & - & - & - & - & نيشاندانى نينّكى تيز & 7 \\
\hline$\% 4,86$ & 9 & - & 6 & -- & - & 2 & 1 & - & - & - & هلرهشهكردن به هيَما & 8 \\
\hline$\% 3,24$ & 6 & 1 & 3 & - & - & 1 & - & - & 1 & - & زمان ليدّرهينان & 3 \\
\hline$\% 2,70$ & 5 & - & - & - & - & 2 & - & 2 & -- & 1 & دروّكردن و هـلخهلَّهاندن & 2 \\
\hline & 185 & 2 & 71 & 66 & 2 & 16 & 7 & 7 & 12 & 2 & كوى كثتى & \\
\hline$\% 100$ & & $\begin{array}{c}1,08 \\
\%\end{array}$ & $\begin{array}{c}38,37 \\
\%\end{array}$ & $\begin{array}{c}35,67 \\
\%\end{array}$ & $\begin{array}{c}1,08 \\
\%\end{array}$ & $\begin{array}{c}8,64 \\
\%\end{array}$ & $\begin{array}{c}3,78 \\
\%\end{array}$ & $\begin{array}{c}3,78 \\
\%\end{array}$ & $\begin{array}{c}6,48 \\
\%\end{array}$ & $\begin{array}{c}1,08 \\
\%\end{array}$ & ريّزلهى سهدى & \\
\hline
\end{tabular}

\section{دورئلهنجامهكاز و شيكردثلومى داتاكان}

له تُهنجامى ئهم تويّزّينهوهيها, تويّزّهر كهيشتنه تُهم دهرئهنجامانهى خوارهوه:-

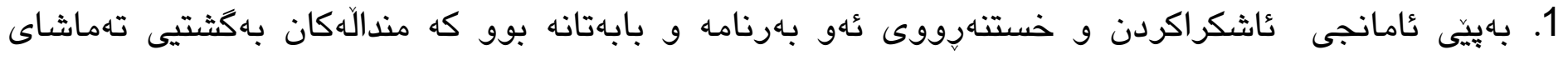

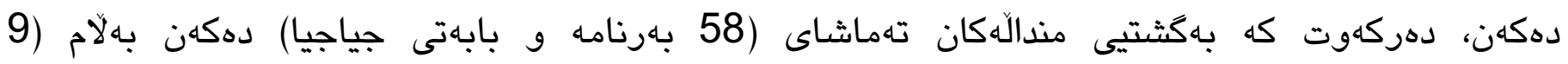
بـارنامه)يان زورترين دووبارهبونهوهى هـهيه. بـتيَّرامان له دهرئهنجامـكان، منداله كورهكان زياتر تهماشاى

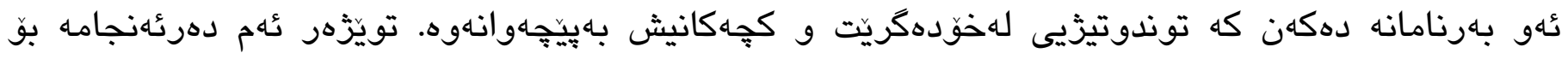

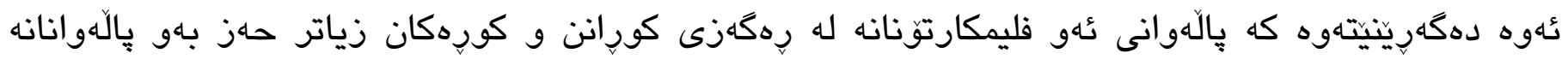

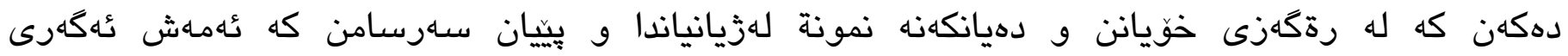


دروستبوونى رهفتارى توندوتيزيى له لاى منداله كورهكان دروستدهات به بهراورد به كجهكان كه زياتر

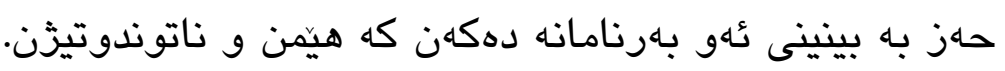

2. سهبارهت بهئامانجى دووهم كه بريتي بوو لهشيكردنهوهى ناوهروكى ئهو بهرنامهو بابهتانهى كه زورترين

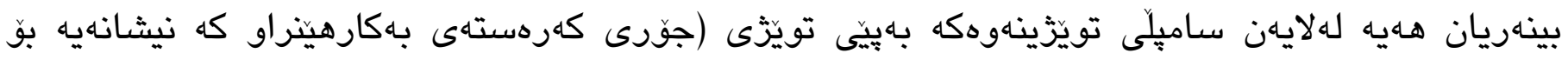

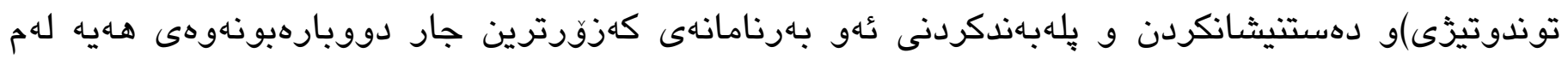

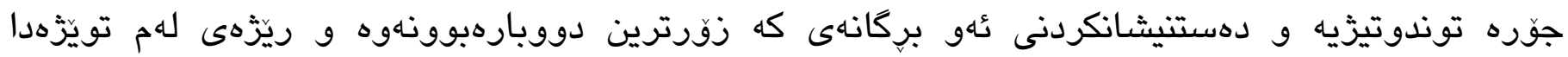

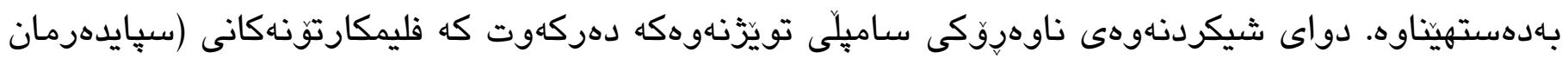

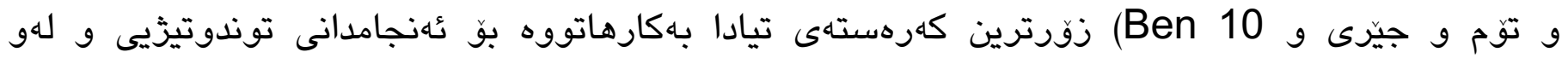

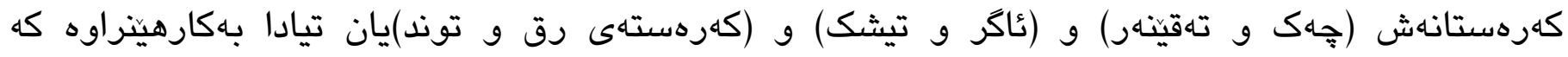

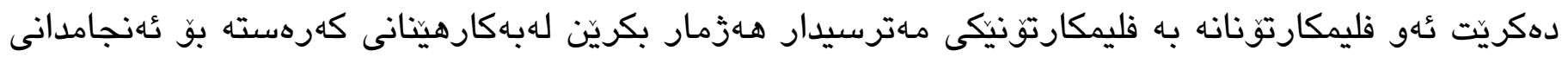

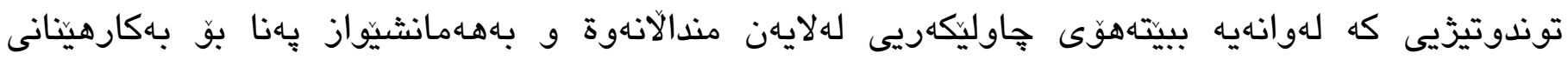
كهرهسته بؤ ئهنجامدانى كارى توندوتيزى بيةن.

3. سهبارهت به شيكردنهوهى ناوهوّكى ئهو بهرنامه و بابهتانهى كه زوّرترين بينهرى ههيه لهلايهن سامِلى

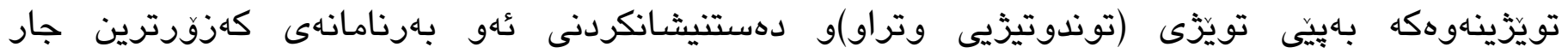

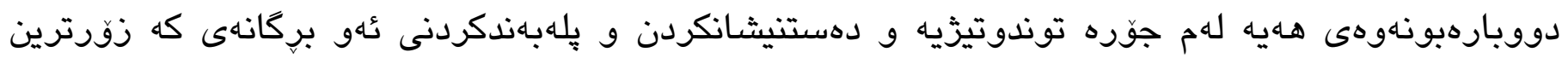

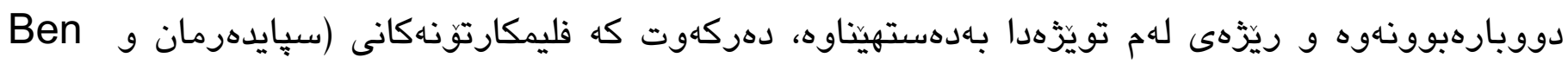

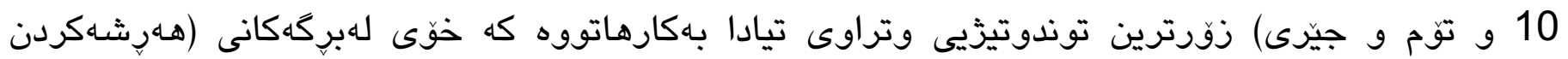

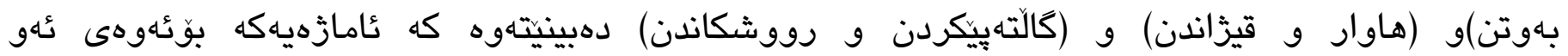

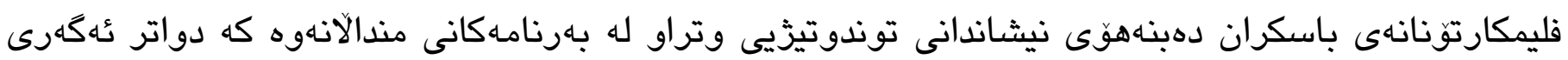

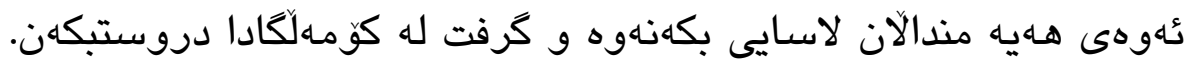

4. سابارهت بهئامانجى شيكردنهوهى ناوهروكى ئهو بهرنامهو بابهتانهى زورترين بينهرى ههيه لهلايهن سامِّلى

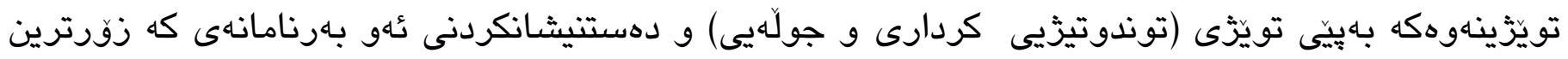

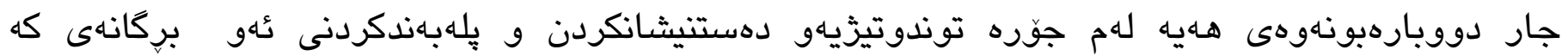

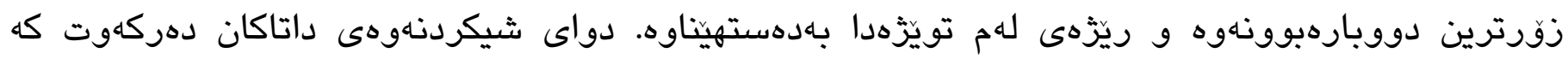

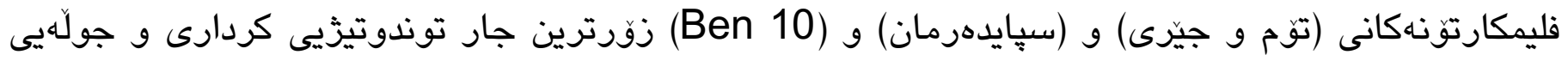
تيادا دوويارهبووهتهوه. لهو كردارانهدا (يياكيثشان) و (يهلاماردان و دهستدريّزى) و (شوينَ ويّرانكرد) 
زوقرترين جار دهيينريّت كه تويَّهر به لايهنيكى نهرينيى و خرايى نُهو فليمكارتونانه دايدهنيت، بهتايبهتى ثٔهو كرداره توندوتيزيانهى كه لهفليمكارتونى (توم و جيّرى)دا هـيه، جونكه لهم فليمكارتونهادا كردارى توندوتيزيى

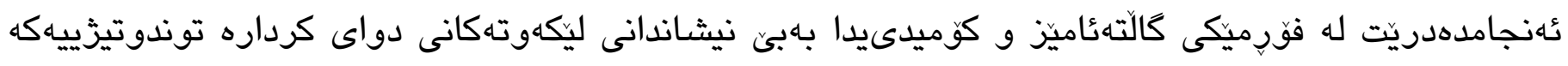
لهسهر بـارامبهر.

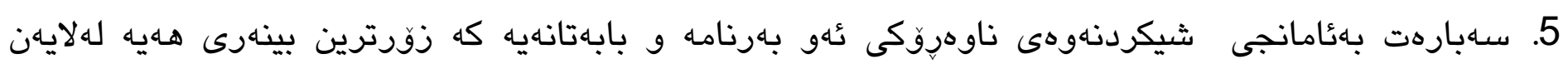

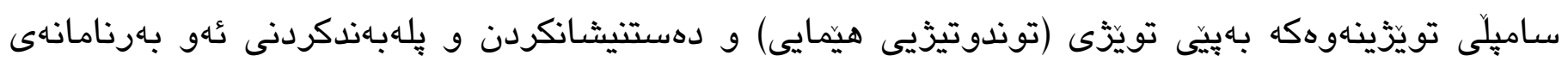
كه زورترين جار دووبارهبونهوهى هـيه لهم جوّره توندوتيزّيه و دهستنيشانكردنى ئهو برِكانهانى كه

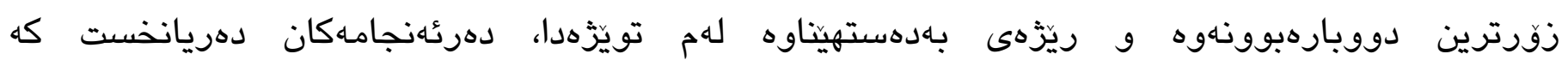
فليمكارتوّنهانى (توم و جيّرى) و (سيايدهرمان) زوّرترين دوويارهبوونهوهى للهجوره توندوتيزيهادا هـهيه كه

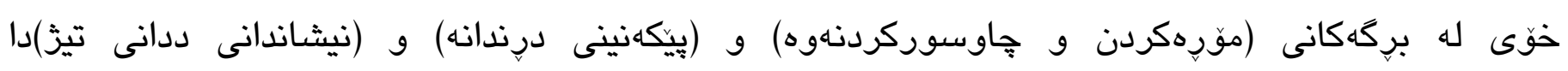
دهبينيتهوه كه دهكريت مندالان ييادهى بكهن و لاسـايى بكهنهوه.

6.

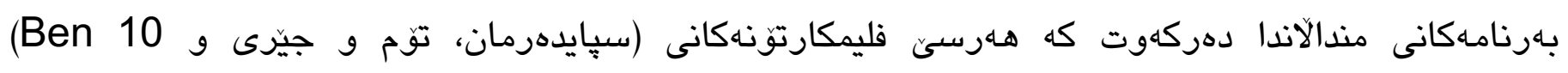
لهزورينهى تويزّهانى توندوتيزييدا بهرزترين ريزّهى دوويارهبوونهوهيان هـيه كه ئامازهيه بو ئهوهى ئهو سنى فليمكارتونه دهبنه مايهى دروستكردنى رهفتارى توندوتيزيى لهلاى مندالان و عاساييكردنهوهى هـنديني كردهوه و وتهى نهشياو لهلاى مندال كه دهبنه مايهى كرفت بوّ خويان و دهوروبهريان. 


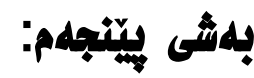 \\ راسيارده و ويتشنياروكان}

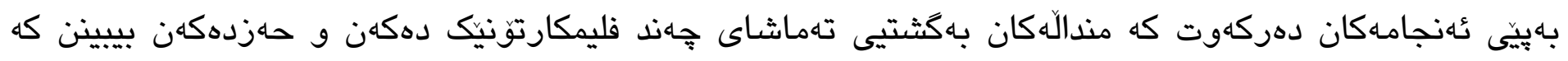

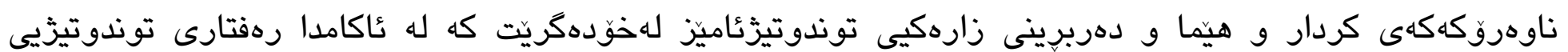

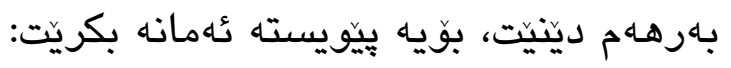

1. وهزارهتى روشنبيري حكومـتى هـريّمى كوردستان، رينتمايى تايبهات به جوّرى ئهو فليمكارتونانه ئاراستهى

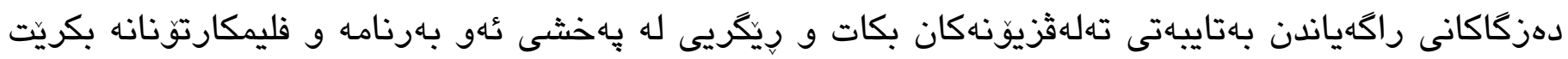
كه توندوتيزيى لهخو دهكريّيت .

2. وهزاردتى روشنبيري حكومـتى هـريّمى كوردستان به بهردهوامى بهدواداجِون و جاوديرى كهنالَكان بكهن.

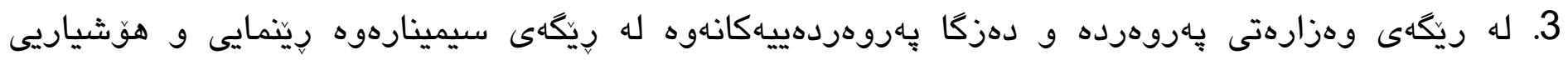

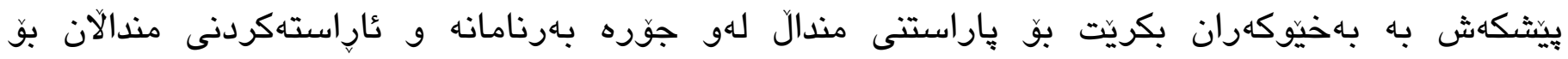
دووركهوتناهوه للهردنى ئهو جوّره فليمكارتوّنانه.

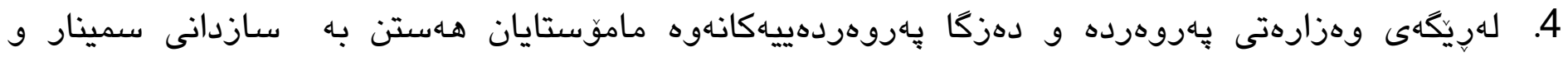

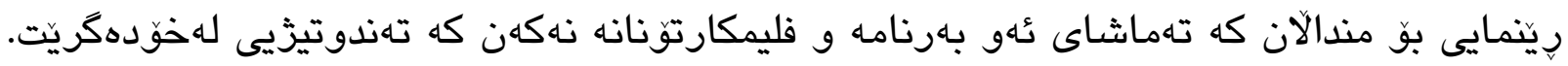

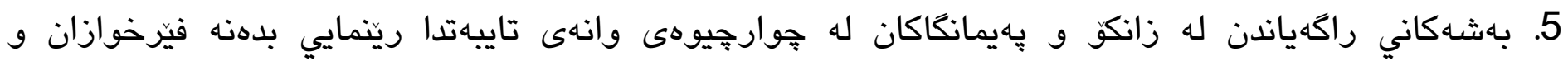

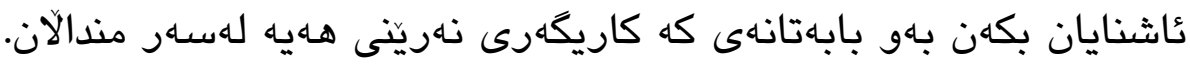

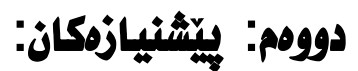

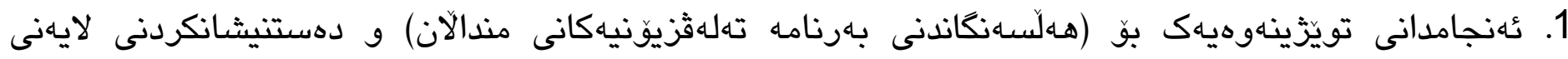
لاواز و لايهنى بههيزّى بهرنامـكانى مندالان.

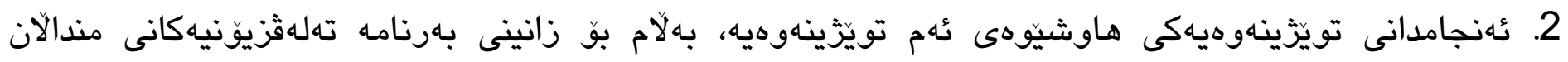
للهسهر باهذا كوماهلآياهتييهكان. 


\title{
The role of childrens television programs \\ on aggrresive behavior of kurdsh children
}

\author{
Jwan Bahaaden Ali \\ Department of media, College of Humanities, University of Sulaimani, Sulaimani, Kurdistan \\ Region -Iraq . \\ E-mail: jwan.bahaden@koyauniversity.org
}

\author{
Salam Nasradeen muhamad \\ Department of media, College of Humanities, University of Sulaimani, Sulaimani, Kurdistan \\ Region -Iraq . \\ E-mail: salam.mohammed@univsul.edu.iq
}

\begin{abstract}
:
The aim of this research is to identify the television programs that children watch in general during interviews with a group of (504) children. After analyzing the content of those programs that were widely viewed according to some categories such as (the tools used for aggression), (verbal violence), (Practical violence) and (symbolic violence). Then the programs were arranged according to the number of repeated the violence in them.

For all this, a questionnaire was prepared to analyze the content of the programs. After doing face validity and Internal consistency to the measure, the researcher analyzed the content of (50) programs from the animated films and the total time was (830) minutes or (13) hour and (50) minutes.

According to all categories of content analysis measure, the results showed that children's programs generaly includes violent scenes and (Spiderman, Tom and jerry and Ben 10) got the first rank in that they contain stylized scenes, and this makes them the most influential cartoon movie on children to learn from them violent behavior and to make social and psychological problems. At the end, the researcher has presented some suggestion and recommendations.
\end{abstract}

Keywords: Role, childrens television programs , aggrresive behavior. 


\section{دور برامج الأطفال المتلثزة في مستوى السلوك العدواثي لدى أطفال الكورد}

قسم الاعلام، كلية علوم الانسانية، جامعة السليمانية، السليمانية، اقليم كردستان، عراق.

jwan.bahaden@koyauniversity.org

قسم الاعلام، كلية علوم الانسانية، جامعة السليمانية، السليمانية، اقليهم كردستان، عراق.

salam.mohammed@univsul.edu.iq
جوان بهاء اللديز على

البريد الإلكتروني : - البر

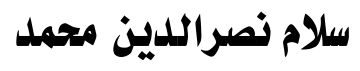

البريد الإلكتروني :

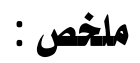

هدفت البحث الحالي الى كشف البرامج التلفزيونية التي تشاهدها الاطفال بصورة عامة خلال اجراء مقابلة مباشرة مع مجموعة من الاطفال البالغ عددهم (504) طفلا , بعد تحليل محتوى تلك البرامج التي حظيت بمشاهدة كبيرة وفق بعض الفئات مثل (نوع الأداوات المستدخمة للعدوان ) و (العنف اللفظي) و (العنف الحركي ) و ( العنف الرمزي) و ثم ترتيب البرامج وفق عدد تكرار مشاهد العنف فيها , ولأجل كل ذلك تم اعداد استبيان لتحليل المحتوى البرامج وتم ايجاد الصدق و الثبات ، ومن ثم قامت الباحثة بتحليل محتوى لـ(50) برامج من أفلام الرسوم المتحركة وبلع الوقت الاجمالي (830) دقيقة اي (13) ساعة و (50) دقيقة ـ اظهرت النتائج ان برامج الاطفال بشكل عام و وفق جميع فئات التحليل محتوي يحتوي على مشاهد العنف , و حصل كل من (سبايدرمان و توموجيري و بن10) على التزتيب الاول من حيث احتوائهم على المشاهد العنيقة وهذا يجعله اكثر الافلام الكارتونية تأثيرا على الاطفال ليتعلموا منهم السلوك العنيف ويكونوا عرضة للاصابة مشاكل الاجتماعية و النفسية، وفي النهاية قدمت الباحثة عددا من التوصيات و المقترحات. 
أحمد حسن القواسمة، و محمد سلمان الخزاعلة. (2017). مظاهر العنف التي تتضمنها برامج الأطفال في قناة Spece Toon الفضائية لدى طلبة المرحلة الابتدائية بالاحساء في الماكة العربية السعودية (دراسة تحليلية. الطفولة العربية).

أحمد محمد عبدالهادي دحلان. (2003). العلاقة بين مشاهدة بعض برامج الاطفال و السلوك العدواني لدى الامحافظات غزة- رسالة ماجستير غير منشورة.

بن حمودة كريمة. (2017). العنف قي برامج الأطفال الكرتونية في قناة سييس تون - دراسة وصفية تحليلية للمسلسل الكرتوني وان بيس(الجزء الأول) رسالة ماجستير غير منشورة.

جويدت فان أفرا. (2003). التلفزيون و نمو الطفل. (عزالدين جميل عطية، المترجمون) القاهرة: المجلس الاعلى للثقافة. رشدي أحمد طعيمة. (1987). تحليا المحتوى في العلوم الانسانية . القاهرة: دار الفكر العربي.

زليخا الصا يم. (2015-2016). البرامج التلفزيونية العنيفة و علاقتها بالسلوك العدواني للتلميذ المراهق, رسالة ماجستير غير منشورة. جامعة محمد خضيرة- كلية العلوم الانسانية و الاجتماعية- قسم الاعلوم الاجتماعية. سامي محسن ختاتنة، و أحمد عبدالطيف أبو أسعد. (2015). علم النفس الاعلامي. عمان: دار الميسرة.

سمية دهامنة. (2015-2016). أثر الرسوم المتحركة على سلوك الطقل الجزائرى-دراسة ميدانية على عينة من أولياء مدينة أم بواقير. رسالة ماجستير غير منشورة في علوم الاعلام و الاتصال.

شعبان مهدية، و بن عيسى أمال . (2011). أثر الرسوم المتحركة في تنمية السلوك العدواني للطفل الجزائري - دراسة ميدانية

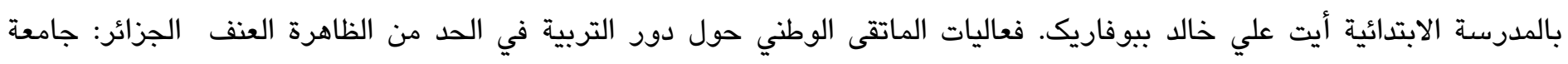
الجزائر.

صلاح الدين محمود علام. (2000). القياس و التقويم النفسي و التربوي. القاهرة: دار الفكر العربي. 
غادة أحمد بعلوشة. (2013). أثر توظيف الرسوم المحركة في تدريس وحدة السيرة النبوية على تحصيل طالبات الصف السادس الاساسي و اتجاهاتهن نحو المادة- رساة ماجستير غير منشورة.

غادة محمود ابراهيم عوف. (2017). دراسة تحليلية عن تأثير لبرسوم المتحركة على طفل الروضة ايجابيأ و سلبيا. International .Design Journal

غبالرحمن بن مبارك بن الماس النوفلي. (2013). أثث العنف المتلفز على السلوك العدواني لدى عينة من أطفال ما قبل المدرسة بسلطنة عمان - رسالة ماجستير غير منشورة.

مأمون المومني، و عدنان سالم دولات. (2011). أثر استخدام برامج رسوم المتحركة علمية في تدريس العلوم في اكتساب التلاميذ للمفاهيم العلمية, دراسة تجريبية على تلاميذ الصف السادس الأساسي. مجلة جامعة دمشق، 3 -4(المجلد 27). محمد جوهري، و الخريجي عبدالله. (1998). طرق البحث الاجتماعي (المجلد ط4). الازاريطة: دار المعرفة الجامعية.

محمد يوسف الزغبي. (2017). أثر مشاهدة الرسوم المتحركة في مرحلة الطفولة على العنف الطلابي الجامعي في الجامعات الأردنية في أقليم الشمال. المجلة الدولية للبحوث النوعية المتخصصة.

هاشم أحمد، و نغيمش الحمامي. (2015). التلفزيون و تأثيراته المحتملة على جمهور الأطفال. مجلة علوم الانسان و المجتمع، 14، $.321-287$ 